Revista Iberoamericana, Vol. LXXV, Núm. 229, Octubre-Diciembre 2009, 1039-1075

\title{
HIPÓTESIS SOBRE CUATRO MANERAS DE POETIZAR: POESÍA PUERTORRIQUEÑA CONTEMPORÁNEA
}

\author{
POR \\ Áurea María Sotomayor MiLetTi \\ Universidad de Puerto Rico
}

Previo

Establecer el corpus poético que se produce en un país requiere una mirada constante, incisiva, contextual. La tarea resulta todavía más ardua cuando el objeto de la reflexión se halla próximo en el tiempo, sujeto necesariamente a las transformaciones sutiles que la temporalidad le impone a toda interpretación de la cercanía. Exige, además, una selección rigurosa que, paradójicamente, pueda rendir cuentas de una lectura integral, pese a que remita a una producción en proceso. Resulta urgente y necesario hacer la suma de esa escritura desde el interior de la literatura nacional a fin de ubicar la literatura puertorriqueña en el mapa más amplio del contexto latinoamericano. No es posible soslayar, sin embargo, la compleja relación de algunos poetas contemporáneos con la tradición de la poesía nuyorican producida en los Estados Unidos desde mediados del siglo xx, lo cual tampoco impide estudiar la gran mayoría de la poesía puertorriqueña contemporánea en la tradición lingüística (el español) que le es afín. No obstante, ni la literatura latinoamericana ni ninguna literatura se produce culturalmente en un espacio unívoco, y aunque el maniqueísmo cultural va superándose teóricamente, aún subsiste en la práctica de la crítica de las literaturas nacionales. En el caso de nuestra literatura, adolecemos de una doble "minoridad", pues somos marginados en el contexto latinoamericano y en el norteamericano. Examinados desde Latinoamérica, la ciudadanía norteamericana empantana de alguna manera nuestra producción cultural, según algunos; y analizados desde los Estados Unidos, nos hemos convertido en "latinos", por lo cual sólo se privilegia en dicha producción una temática identitaria y una actitud lingüística bivalente en el momento de estimar su inclusión en dicha tradición. En síntesis, desde ambos puntos de vista, desde afuera, se le asignan a la literatura puertorriqueña unos reclamos de homogeneidad fundados en expectativas y convenciones provenientes del marco político-cultural de quien consume, llámesele mercado, crítica o institución cultural. Parecería que la literatura puertorriqueña, por el solo hecho de su origen (Puerto Rico), plantea 
conflictos críticos que, de entrada, rebasan lo literario, desequilibrando la mirada del texto y sobrevalorando los contextos, leyendo la producción sólo en función de las exigencias del consumo. Hay un trasfondo político de ciertas actitudes promovidas en Latinoamérica que, por razones de un falso purismo cultural y lingüístico, desdeñan toda manifestación literaria proveniente de Puerto Rico, aún cuando mayoritariamente esta se produzca en español. Así también, en los Estados Unidos, la periferia imperial sólo ve lo que quiere, condicionando y asignando a la literatura producida por los autores latinoamericanos los temas y la lengua que en el plano económico designa a las minorías. A este panorama político y culturalmente complejo hay que añadir la poca crítica sobre poesía contemporánea en nuestras letras, lo cual produce un efecto acumulativo de textos poéticos que, a efectos de su visibilidad pública, a lo sumo gozan de una presentación y una reseña, pero que no son integrados en una lectura más abarcadora, crítica e histórica, del proceso literario. Si bien son los poetas mismos quienes se han ocupado fragmentariamente de la crítica de poesía, no existe un cuerpo sistemático de especialistas que vaya sopesando objetivamente dicha producción, ni siquiera desde un punto de vista bibliográfico. Le compete a los centros de educación superior ir creando espacios y actitudes que estimulen el vasto y abandonado campo de la crítica sobre poesía. De no hacerlo, proliferará el error, la parcialidad, el compadrismo y la ignorancia sobre un género clave en nuestra tradición literaria. Sin embargo, para consuelo de muchos, principalmente de los poetas, en la última década han surgido editoriales en donde la poesía ocupa un lugar prominente, a saber, Fragmento Imán (colección El arco invisible), Isla Negra Editores, la colección “El farolito azul” de la editorial Callejón, y la editorial Terranova. ${ }^{1}$

\footnotetext{
1 Cuatro editoriales independientes, Callejón, Isla Negra, Terranova y Fragmento/Imán, se han ocupado de mantener viva la prolífica producción poética desde finales de los noventa hasta la entrada del nuevo siglo. Sus directores son el poeta y editor Carlos Gómez Beras, de Isla Negra; Elizardo Martínez, de Callejón; Eugenio Ballou, de Fragmento Imán; y el poeta-editor Elidio La Torre Lagares, de Terranova. Fragmento Imán ha publicado unos cinco títulos de poesía de Noel Luna, Nora Dávila, Irizelma Robles, Rafael Acevedo y Sylvia Figueroa. La colección “El farolito azul” de ediciones Callejón ha publicado también cinco títulos, de Rafael Acevedo, Mayra Santos, Rosario Ferré, Urayoán Noel y Áurea María Sotomayor. La editorial Terranova se ocupa exclusivamente de poesía y cuenta entre sus autores a Noel Luna, Kattia Chico, Guillermo Rebollo-Gil, Néstor Rodríguez, Mara Pastor, Javier Ávila y otros. La editorial Isla Negra ha publicado más de treinta y cinco libros de poesía inicialmente bajo la colección "La caja negra”, y tiene entre sus autores a Guillermo Rebollo-Gil, Israel Ruiz-Cumba, Rafael Acevedo, Julio César Pol, Juan Carlos Quintero-Herencia, Irizelma Robles, Chloé Georas, Raúl González (Gallego) y otros. La extinta Libros Nómadas publicó tres libros de poesía entre su colección, de Lilliana Ramos Collado, Chloé Georas y Áurea María Sotomayor. Así también figuran editoriales vinculadas a instituciones tales como la editorial de la Universidad de Puerto Rico, que ha publicado textos de Noel Luna, Etnairis Rivera, Edwin Reyes, Iván Silén, Ivonne Ochart, Servando Echeandía y José María Lima, entre otros, o el Instituto de Cultura Puertorriqueña, cuya nómina de poetas es ciertamente extensa. Debe considerarse, además,
} 
El primer supuesto de este trabajo consiste en reconocer la complejidad del género mismo de la poesía en cuanto a las lecturas que esta pueda suscitar, pues se trata de un discurso cuyas coordenadas y tangentes resultan más ambiguas y, por ello, menos dóciles que las narrativas. ¿Qué leer en un poema? ¿Qué decir de la voz que lo sostiene? ¿Cómo abordar los temas en que incide? Podríamos disponer de dos vertientes, buscando en el texto una razón temática que lo vincule al contexto histórico, político o económico del cual surge o una razón lingüística que sopese el artefacto verbal del que está hecho. Ya esta opción nos fuerza a dirimir la profunda dicotomía de estimar la poesía como un discurso referencial o autorreferencial, es decir, de la poesía como comprensión o expresión. Si algo me interesa de los poetas que consideraré en este ensayo es su quebradura de esta falsa distinción, subrayando cómo la expresión no puede prescindir de la comprensión como piedra fundamental. Acaso no se pueda "decir" a menos que se piense previamente en cómo decirlo y se necesite dedicar gran parte del hacer poético a pensarlo. Uno de los aspectos más conspicuos de la poesía puertorriqueña contemporánea es la reflexión que sobre la poesía es realizada por los poetas en sus textos, a tal punto que el libro de poesía deviene una vía de presentación del arte poética. En los poetas líricos que me propongo abordar, hacer poesía no se realiza de una sola manera, sino mediante el poema clásico lírico, el poema en prosa, el poema "en traducción” y el poema prosaico. En este sentido, abordaré la obra particular de cuatro poetas cuyos libros se publican en la primera década del nuevo milenio, a saber, Noel Luna, ${ }^{2}$ Sylvia Figueroa, ${ }^{3}$ Chloé Georas ${ }^{4}$ y Guillermo Rebollo-Gil. ${ }^{5}$

la importancia que tiene la edición de autor en nuestra tradición literaria, al igual que en la tradición latinoamericana, y la labor artesano-editorial del poeta y editor joserramón melendes a través de su editorial qeAse, bajo cuyo sello se publica la primera antología de jóvenes poetas universitarios (Antología de la sospecha), que devendría luego en la llamada "generación del setenta”, y textos claves de la poesía puertorriqueña de poetas ampliamente reconocidos, tales como Juan Antonio Corretjer, Francisco Matos Paoli, José María Lima y Ángela María Dávila. Falta insertar esta extensa e intensa producción en el imaginario poético latinoamericano y trasatlántico; esperamos que este ensayo constituya un esfuerzo que abone ese proyecto.

2 Nace en 1971 y tiene en su haber Teoría del conocimiento (2001), Hilo de voz (2005), Selene y Música de Cámara (en prensa). Acaba de publicar Fiel fugada, su edición crítica de la obra de Luis Palés Matos. Es profesor de humanidades y de literatura comparada en la Universidad de Puerto Rico.

3 Tiene en su haber un volumen de poesía titulado (pAra mirar de cErca) en el 2007 y dos libros publicados por la vía artesanal: The Truth about Cats and Dogs (1999) y Los días que fueron (2006). Es profesora de literatura radicada en Toronto, Canadá.

4 Rediviva lost in trance.lation tiene dos ediciones, la primera por Libros Nómadas en 2001 y una segunda edición como libro-objeto bajo el sello Isla Negra, en 2004. Es profesora de derecho y artes visuales y de derecho cibernético en la Facultad de Derecho de la Universidad de Puerto Rico.

5 Sus libros se titulan Veinte (2000), Sonero (2003), Teoría de conspiración (2005) y La carencia (2008). Es profesor de sociología en la Universidad de Connecticut. 
Cada cual aborda cuatro aspectos cruciales del lenguaje y sobre ello constituyen su poética. Esta agudeza, que reúne el pensar y el decir en una unidad poética llamada "libro" permite establecer distinciones entre unas y otras promociones poéticas, así como delimitar el segmento de una producción abundante que por razón de su complejidad no pretendo abarcar en este ensayo. Me interesa leer la "razón" de su hacer poético, pues constituye esta una de las claves que relaciona esta promoción de poetas que nacen después de 1970 con la llamada generación del setenta, nacidos en los cincuenta, estableciéndose una línea directa entre ambos. La insistencia de estos poetas en formular una poética y de construirse a partir de una voz en extremo consciente de sí es un rasgo definitorio y complejo. Como intérprete, me interesa ceder al dictado de cada una de sus voces y reconocer sus diferencias respecto a qué hacer con/para/pese el lenguaje. Esto habría que colocarlo en el contexto de que usualmente la crítica rehuye de la poesía, por razón de la dificultad de hallar un discurso alterno que la "glose" comprensivamente, desde una doble perspectiva estética o política. Intento remitirme a este corpus poético a partir de lo que el texto me impone, cifrando en éste lo que Paul Valéry consignó en el binomio "Poesía y pensamiento abstracto", al considerar su aspecto cognoscitivo (1314-39). Pero a la vez, habría que colocarse en el lugar de Maurice Blanchot cuando sugería que el lenguaje fascina independientemente de la voz (quien dice) y de la comprensión (de quien escucha). ${ }^{6}$

1. El ojo justo, ¿'Será posible? La poesía de Sylvia Figueroa

La metáfora central del texto de Figueroa(pAra mirar de cErca) remitea la acción de mirar, y cada una de sus secciones, a saber, "montar un ojo", "proyección” y "la óptica ondulatoria”, reflexiona sobre la imposibilidad de discernir la distancia entre el sujeto de la enunciación y el objeto de la contemplación. El poema correspondiente al título del libro registra dos instancias de dicha actitud:

Esto es un cuadro. Apunto lo que deseo mirar en él.

Usualmente me dejo llevar por lo que más perturba.

El detalle asusta, pero no dejo de observarlo.

Estoy afuera. Mientras me mira, me dice que no estoy afuera:

me habla. Lo miro y me contradice, aún más:

no me correspondería si le hablara.

Como ese detalle obviado que no responde nunca.

Aquél que aseguraba que no sería más una espectadora, Acercándome de algún modo, dejándome ser.

\footnotetext{
6 Me atengo a la paráfrasis realizada por Paul de Man de la frase de Blanchot en su libro La part du $f e u$, “le langage ne suppose personne que l'exprime, personne qui l'entend".
} 


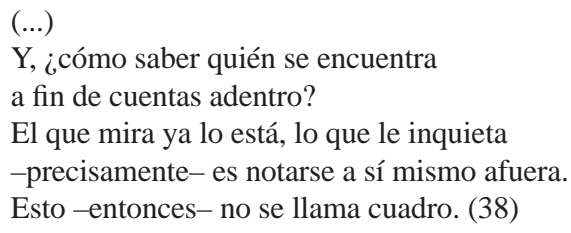

En este libro (hacia ese cuadro) la hablante intenta mirar objetivamente, reconociendo que es un ejercicio imposible y, lejos de sopesar racionalmente y discernir lo que hay allí, en el cuadro que se muestra, no hay forma de evitar reconocer que se trata de un ensamblaje, y la mirada depende del lugar que ocupa ese o esa que se desea como su espectador. Más que mirar, entonces, el libro registra el deseo de mirar, por lo cual el centro no se halla fuera sino siempre adentro, fundiéndose en la voz poética lo mirado y el mirar, quien escribe y quien lee. Acaso no haya mejor reflexión sobre un ars poetica que este pliegue emblemático operando sobre la superficie de un texto doblado -en el poemario, la letra a la izquierda se mira en la imagen que ocupa sin ilustrarlo el lado derecho de la página- como Narciso sobre la superficie de sus propias aguas. ¿Qué es lo justo aquí? ¿Es el reflejo justo? Es decir, ¿̇aspira a la mimesis? En ese doblez está el lenguaje mirándose mirar, sabiéndose impreciso, deformándose por efecto de las cosas que intervienen en la trayectoria de la mirada. El resultado es la cartografía interior, obsesiva y reverberante que regresa siempre, la paranoia del vol-ver, actuando como una vuelta sobre sí misma y trucando al lector que piensa que, sólo porque el léxico invita a lo geométrico, transita un camino de líneas rectas e infinitas. Infinitas sí, pero no rectas, por impredecibles, pues lo que parece un lenguaje orientado hacia un fin, sobrio y preciso, va encallándose en los pozos de la reiteración densa, opaca e incierta, como en un barroco conceptual.

Quizás sea importante la colocación visual de lo racional o lo contrario. La idea recogida, en ambos casos.

La sucesión de lo que se dice. El espacio dramático, el tiempo mostrado. Así se produce el golpe, como un recuerdo materializado; dirigido a quien lo lea como suyo situándose en esa zona de nitidez. La distancia focal se extiende delante y detrás del plano del enfoque. El campo y su profundidad resaltan la escena pero el ojo se dirige, después de todo, hacia su propio fin. ("Profundidad de campo al cuadro” II: 4) 
Más que de rectas, se trata de elipsis y lo que parecería una escritura sobria se torna barroca. En suma, lo que se mira viene de adentro, por lo cual remite a la especulación. La ansiedad de mirar, más bien de ver, pese a la miopía que produce la proximidad, se refiere a lo mirado, al cuadro, fuente de lo que se especula desde el primer poema de la colección:

Pero qué del cuadro -así- cuadrado y sin su cubo?

¿Se alargaría hasta convertirse en la forma más imposible:

un rectángulo que el ojo intenta arrastrar y no puede?

El par, el impar. La esquina. (“El encuadre y su función” 2)

La voz poética se ejercita en dudar que se pueda montar un cuadro o contemplar el plano que ocupa, precisamente por la densidad que es. Cuando leemos, advertimos el poema a la izquierda y, además, las imágenes que ocupan el lado derecho del poemario, las cuales devienen, en su relación al texto verbal, manchas a descifrar, límites a poblar, vacíos que implican silencios, sugerencias a ser llenadas, contrapuntos, o la pareja figurativa de la letra. ${ }^{7}$ La voz poética pretende ejercer su propia lectura, poniendo en frente, digamos, esa mancha de tinta que es el fragmento de video o el acercamiento (close up) de la foto o la demarcación de cuatro líneas que formulan cuatro ángulos cuyo interior está vacío. De ahí que al final de la travesía la voz poética insista en un verbo reiterado que le imparte a este libro su mayor unidad: creer. Así, al principio, la voz poética se figura mirando o mirándose mirar al comenzar con una premisa: la acción racional de dibujar un paisaje, y concluye con un paisaje indeterminado en el que, primordialmente, se cree. La marcha de la razón sobre el paisaje que se crea se define impecablemente en el verbo "creer", que nos lanza hacia dos lugares: el yo o el otro, y entre ambos, el descubrimiento. ${ }^{8}$ Si nos atenemos exclusivamente a la disposición de textos e

\footnotetext{
7 Véanse, sobre todo, “Término”, “0=¿0?” y “Mañana”, de la sección “Proyección” y los tres poemas que inician la sección del libro "Montar un ojo”, los cuales constituyen el relato segmentado de un acercamiento de la cámara a un cuadro - atravesado por una rama que figura como elipsis- dentro de una cuadrícula. No en vano los poemas se titulan "I. El encuadre y su función”, "II. Profundidad de campo al cuadrado” y “III. Elipsis formal.” Durante la presentación del libro el 25 de abril del 2008, estuvo presentándose el video completo de la autora, algunos de cuyos fragmentos se reproducen en el libro.

8 Travesía por la desilusión leída como logro cognoscitivo del descubrimiento de lo que es o no es el amor, también, según muy cautamente indica el texto. En “Término” y en “Todo es”, la aserción femenina: "Voy a paso lento, quieto, /aceptándolo por contrariar /al que he supuesto mi verdadero paso. /He creído tomar prestada otra temporalidad, /y aquello que es es lo que no es, si creo” (28, énfasis mío). En el poema “Sin título, ’11 por 1” se lee: “Había creído que el agua no llegaría hasta el otro lado. /Pero al otro lado, descubrí que lo creído era nada menos /que una falsa conclusión. Del otro lado, toda conclusión /es tangencial. He llegado al punto de encuentro. /El reloj indica la hora, pero no apareces” (46 énfasis mío).
} 
imágenes, una casa vista en la lejanía cuyo espectro se cuadricula tras los barrotes de una ventana, calles desoladas, lluviosas, frías, interiores habitados por el silencio, rostros que se repiten desfigurados por la luz u ocultos por las sombras de perfil o de espaldas, o el sesgo de una cámara, los bordes quemados de casi todas las imágenes, el énfasis en la demarcación, todas sugieren formas del habitar que ocurre en el espacio de la memoria que las encierra muy sutilmente en el paréntesis que configura la mirada/lectura. Al contrario de lo que significaría abrir el lente para que entre la luz, aquí el hacerlo lindaría con enceguecerlo. De ahí que el lenguaje cauto, preciso y geométrico del poemario no aspire a decir, ${ }^{9}$ lo cual sería una forma de la comprensión que evade el hablante poético, sino a sugerir, según las sombras o según la deformidad que éstas producen:

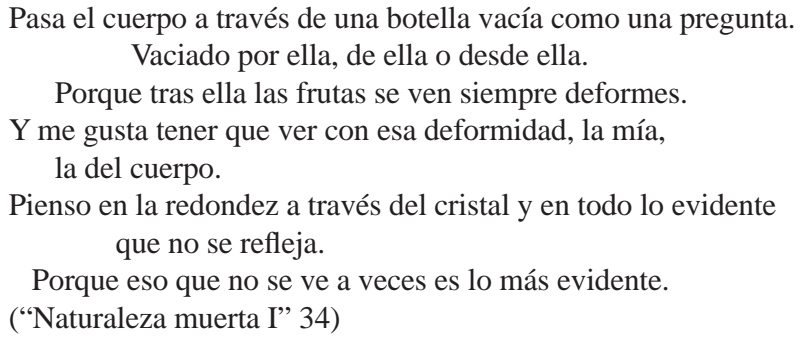

Aquí lo barroco es también optar por el poema en prosa como una forma diferente de poetizar y el poema ensaya, a partir de una travesía por el conocimiento, formular poéticamente otras avenidas: en vez de rectas, curvas; en vez de afueras, adentros. En lugar de un sitio privilegiado o racional desde donde mirar un cuadrado con densidad, un espacio borroso cuya aprehensión depende de un estado de ánimo donde la geometría de la totalidad, o del círculo, hace del blanco (el cuadrado que es metáfora del poema al principio del texto) un objeto móvil, incomprensible sin su historia, sus contextos, sus antes y después. De nada sirve entonces la línea recta y económica que orienta un camino sin el lujo de los titubeos. Dice el poema final:

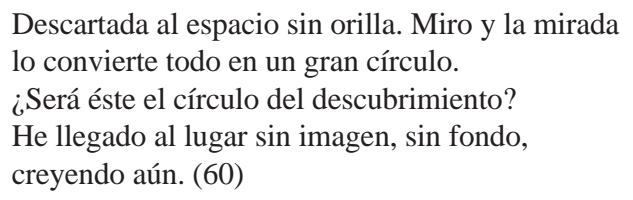

\footnotetext{
9 En "Promesa" se afirma: "Ya no digo, /pues decir conlleva no dejar que me entiendan. /Y entender, a su vez, es una aceptación que no quiero admitir.” (16).
} 
Crear es creer, podría ser la síntesis verbal del libro de Figueroa. La voz poética presenta sus coordenadas saboteando la fragilidad de una objetividad imposible. Desde ahí no pueden trazarse líneas rectas, se carece de una teleología, se emborrona el paisaje, el cual no se intenta des-cubrir, sino re-plegar visual y verbalmente, y cada vía (la verbal y la visual) requiere estrategias diversas. El texto va acotando la imagen en su despliegue paralelo a medida que lo hojeamos (ojeamos), y su sentido sólo es legible si se quiere, es decir, si se cree.

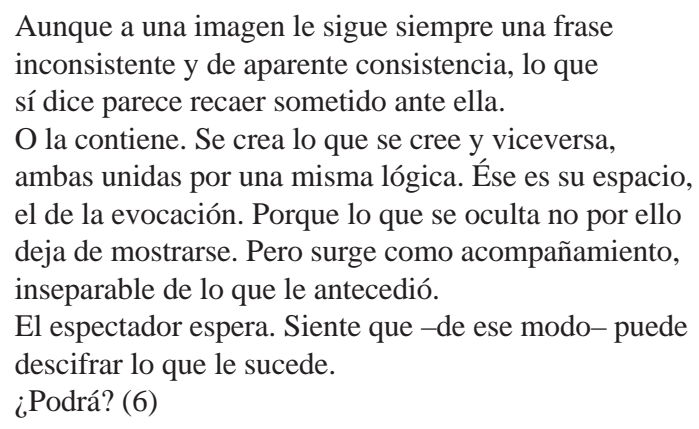

¿Existirá alguna diferencia entre la verdad y lo verosímil? Macedonio Fernández mencionaba que lo que hace un relato son las “y”, criticando con ello el sentimiento de causalidad que un narrador le imparte a una historia. La diferencia no parece importarle a la voz poética, sabiendo desde un principio que no hay certidumbres y que, lejos de poder organizar linealmente las imágenes, todo ocurre simultáneamente. El hallazgo cognoscitivo depende de las intensidades, y ocurre "después de algo muy grande": ${ }^{10}$

Esto es un cuadro: no porque intente imprimir color sino porque ésta es la forma que resalta el sentido del momento: devolver la mirada hacia el centro. Aunque no por eso creo que deba ocupar el mismo espacio enfático, a veces esa mirada particular y precisa revela lo que los sueños realizan inevitablemente. No creo necesario resumir el sueño; sí el temor (quizás de ese modo lleguemos más fácilmente). El temor es brutal. (32)

Ante la aserción no tan contundente de "se dice que un cuadro acomoda fácilmente una explicación racional”, termina negando la posibilidad de que exista

\footnotetext{
10 "Del archivo y su evidencia" (18) es un poema fundamental en la poética de Figueroa. Se posee o se conoce sólo cuando regresa en la memoria, es decir, cuando no queda nada por hacer.
} 
un cuadro. ¿Cómo es posible mostrarlo, señalarlo, usar el deíctico en dirección a este? Se trata de la pregunta sobre el punto de partida. De ahí el léxico que comienza cuestionándose de manera wittgensteiniana el color y cómo denominarlo, cómo describirlo a un ciego, la manera de contextualizar la percepción. Ya al final del libro se despliega un léxico más sensible (menos geométrico) y la sección "óptica ondulatoria” le permite acceder a una cierta revelación, y al lenguaje, a mantenerse alerta sobre algo, aunque no sobre un referente dado sino sobre quien lo construye, un sujeto que denota haber logrado conocer, dado el tono que utiliza. Acaso a lo que se haga justicia aquí entonces es al hallazgo del tono, de la intensidad que resulta más pulcra, precisamente por el léxico que la cerca: le hace un espacio límpido al "temor". Al surgir ese contraste, todo el resto sobra, incluyendo la trama. Esa justicia que se le hace a la subjetividad, paradójicamente se filia con la materialidad de la evidencia a la que se alude en el poema ya citado, "La evidencia y su archivo". Lo más interesante del texto es el rastro de verdad que irradia de la palabra "evidencia”, como si constituyera esta la base de la certeza. La voz poética está consciente del espacio que ocupa, algo que le imprime seguridad, sobre todo a lo que se dice. Cito el poema en su totalidad:

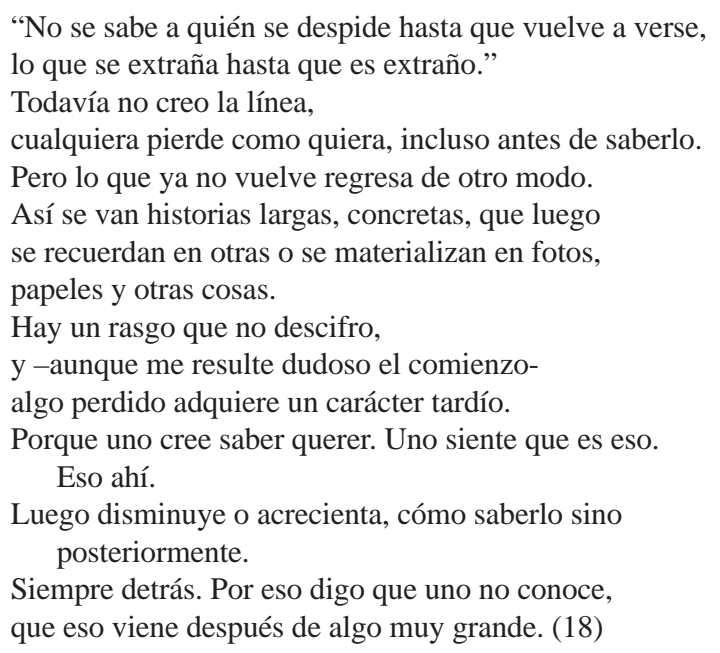

Si al principio del libro la hablante no sabe, al concluir conoce, y el poemario expone esa transformación. ¿En virtud de qué se produce el cambio? El poema deslinda la ignorancia vis-à-vis el conocimiento al centro del texto, en el momento de la imposibilidad de descifrar. Es decir, el signo cuyo código se desconoce, acompañado por frases semánticamente bivalentes tales como "Se extraña hasta 
que es extraño”, “cualquiera pierde como quiera”, y la ambigüedad de los versos sobre el colmo de lo extraño o de lo que se pierde contrasta con la materialidad de la evidencia. Pero esa prueba es, irremisiblemente, producto de una lectura en la que obra la voluntad, consistente en “uno cree saber querer”. La díada entre el creer y el saber, el creer y el crear, es un efecto del sentir. Y la evidencia más contundente de ello la marca el texto al insistir en vocablos que apuntan a lo inefable: “eso”, “ahí”, puesto en la perspectiva cronológica del “después”. Sólo entonces, en virtud de la comparación, la hablante concluye lógicamente, racionalmente, "que eso viene después de algo muy grande”. Lo que viene después es el "eso”, sólo que antes se "siente” y sólo después se "sabe”. El centro del conocimiento obtenido, sin embargo, se elude nombrarlo o adjetivarlo y se insiste en aludirlo como “eso”, “ahí”. Sólo en contexto podría figurarse, interpretarse o descifrarse; permanece sitiado o cercado por los signos de lo que ortográficamente la hablante, hallando el gesto definitorio, destina a lo enclaustrado, la “cámara oscura”. El lenguaje es un modo de decir el sigilo del sujeto del texto, como una monja en la celda de su paréntesis.

Hay una voluntad evidente de estructura en (pAra mirar de cErca). Se repite a lo largo del libro la vuelta sobre sí misma de la voz en una doble posición de mirada y mirante, de proyectar en el objeto a un sujeto, de estatuir desde un inicio que el fin es el principio, de saber que se trata de una curva en lugar de una recta infinita, que autora y lectora son indistinguibles. La estructura en forma de X de muchos de los poemas, o la aseveración hecha al inicio de un poema y la negación con que terminan, metafóricamente, el retruécano que no se oye pero que se revela en las estructuras lógico-sintácticas, y no auditivas, constituyen la forma poética a la que hay que remitirse para ver operando en frío a esta voz. El mirar se produce dentro del paréntesis que provee el título, un espacio cerrado donde, al decir deleuziano, no hay ventanas ni aberturas. La ventana la piensa (crea/cree) la voz que va saliendo de la contemplación y por ese resquicio se escapa la aserción mayúscula: la dificultad de plantearse el afuera como evidencia, abandonar el rastro de la sombra a su devenir propio y afirmar con fuerza su propia voz en el re-conocimiento del querer. La travesía del sujeto poético se resuelve indicando una causa, un "para” ya insinuado en el título, un objetivo para el mirar, no sin antes aludir irónicamente a los contextos, a sus secuencias, a sus cortes, a sus interrupciones y también a la voluntad que significa crear un relato, una relación, un predicado para un sujeto consciente de que creer es crear. Hallar esos dos verbos es el "acontecimiento" en sentido leibniziano, ${ }^{11}$ digamos, de la voz poética en el poemario, y también el

11 Véase Deleuze “¿Qué quiere decir: ‘Lo que se relaciona a la existencia y al tiempo”? Eso es el predicado. Lo que se relaciona a la existencia y al tiempo se dice de un sujeto. Pero lo que se relaciona a la existencia y al tiempo no es un atributo, con todo el rigor de la palabra atributo, eso no es un atributo. ¿Qué es? Es un acontecimiento”. [...] “De todas maneras cada mónada expresa la totalidad del mundo. Cada mónada expresa el mundo, cada unidad sustancial expresa el mundo, en 
acontecimiento de esta, su lectora. Afirmar que algo es un cuadro es relativo al sujeto, al igual que denominar los colores de un objeto no es una atribución, sino un acontecimiento, por eso, la visible ausencia de adjetivos en el texto. La alegoría del libro, el "para” de la mirada, podría ser este fragmento que afirma en lo exterior el revés de su deseo, que permitiéndose un resquicio, dice:

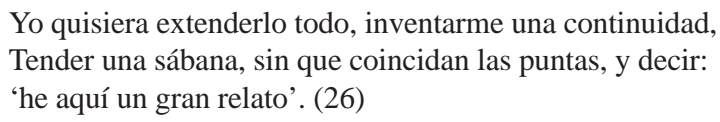

\section{2. “Sílabas DE VIENTO”: LA POÉTICA DE NoEl LunA}

Teoría del conocimiento, el primer libro de Noel Luna, revela a dos personajes provenientes del mito: Orfeo sigue a Eurídice, figura de la huída, cantándole para que regrese, pero ésta se halla entre las aguas del Leteo y aunque su voz interviene en el texto (se usan las itálicas cuando ella habla), lo que más perturba al hablante sobre ella es la fuerza de su irrealidad y su capacidad para la metamorfosis:

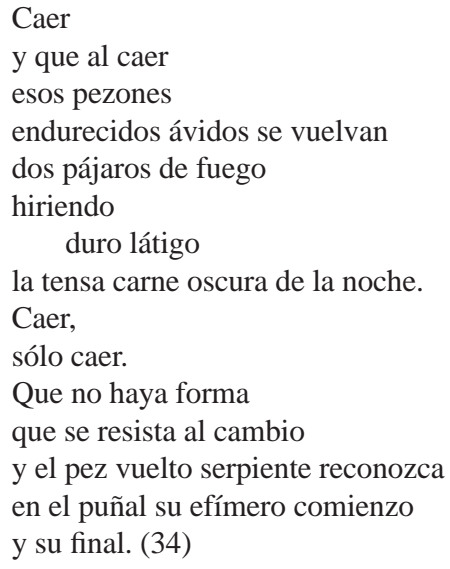

En este libro ya se hallan las imágenes de la poesía posterior de Luna: gota, semilla, agua, sangre que se derrama o penetra en lo oscuro brotando de la boca y fecundando la página, invocando con ello a muchos de sus poetas medulares: Gorostiza, Lezama Lima, Luis Palés Matos. Entre la materia líquida y la aural hay

otros términos el mundo es la manera de ser de las unidades sustanciales. El mundo es el predicado del sujeto. Es la manera de ser de la unidad sustancial. ¿Qué es eso? Llamémoslo una porción, o un nudo. Es el gran nudo barroco". 
un erotismo en esta poesía de la palabra que horada, rompe, penetra, haciéndose espacio con la voz que sale de sus labios. En medio del verso la más clara referencia a una materialidad sobre la que se cimenta, casi conjurando a través de verbos imperativos, centrales en toda su poesía, el conocimiento poético:

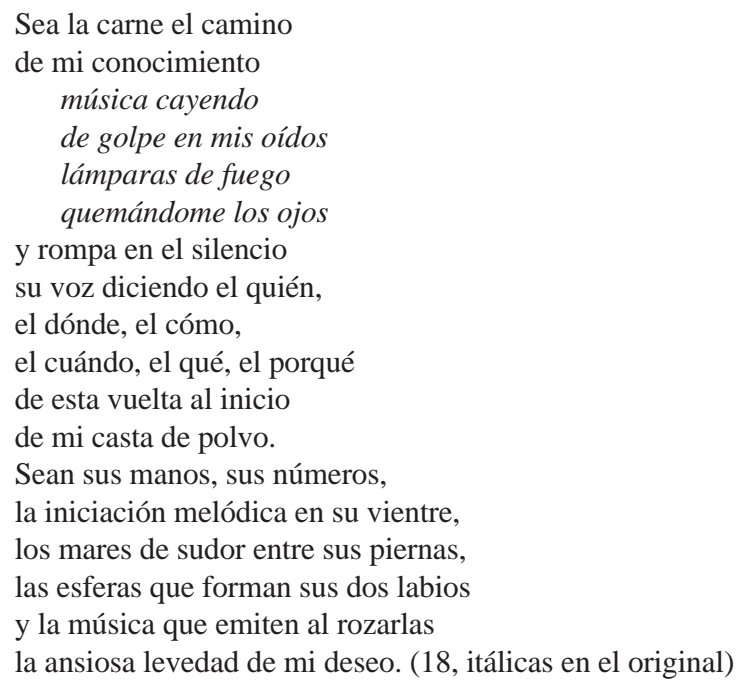

Distingue a Luna de Palés, uno de los poetas más importantes del siglo xx en Puerto Rico (junto a Francisco Matos Paoli, Julia de Burgos y Juan Antonio Corretjer), el destacar la materialidad y la sensualidad de la palabra poética, al dedicarse la voz poética a reflexionar en el lenguaje como dificultad. Si en Palés se le llama "la caza inútil” a la imposibilidad de asir a la amada Filí-Melé, que es representación de la poesía, bien podría decirse de Noel Luna lo que Margot Arce comentó del Palés de "Puerta al tiempo en tres voces" hace varias décadas: "se ha elevado sobre una imagen implícita y subyacente que le sirve de cimiento: la comparación de la relación entre el poeta y Filí-Melé con la cacería; pero el cazador falla y no puede cobrar la deseada pieza”. ${ }^{12}$

Hilo de voz, segunda colección de Luna que reúne los textos Eros/Ión, El libro de la noche e Hilo de voz, insiste en el tema de la escritura. Si El libro de la noche (1995-1996) puede leerse temáticamente a partir de la desesperación y la pérdida, los restantes describen una búsqueda metapoética. En El libro de la noche hallamos

${ }^{12}$ Referencia a un estudio crítico de Margot Arce, en la sección titulada “Abece”, bajo la palabra “caza inútil”. Fiel fugada: Antología poética de Luis Palés Matos (251). 
a un hablante sumido en un cuarto vacío, devastado y oscuro donde a la lumbre de un cigarrillo se sueña la biblioteca de Alejandría quemándose. Durante esa noche se comienza a disolver la identidad, y el "tú" del apóstrofe, que es la noche y la amada, da paso a una palabra que se descubre como forma para posteriormente reconocer a su dios, la poesía, así como su principio y fin, el silencio. Eros/Ión (1992-1997) es “erosión”, el desgaste producido en la superficie del cuerpo por el roce de la acción de otro. No es al crítico inspirado (Ión) a quien Sócrates/Platón celebra casi irónicamente al concluir su diálogo, sino al poeta involucrado en su decir divino. Luna, el poeta, invoca al otro que es su tradición, a través de la forma "soneto" y de epígrafes o citas que funcionan a manera de invocación, rozando su escritura y grabándola a manera de un tatuaje. La escritura es uno de los términos de ese tú al que se apostrofa, encarnada inicialmente en la amada como fuente de inspiración. El hablante recorre las calles de una ciudad fantasmal en una noche incendiada por la memoria, divaga por la forma que le impone su tema y termina fragmentándose en sílabas de aire y espuma al concluir su jornada.

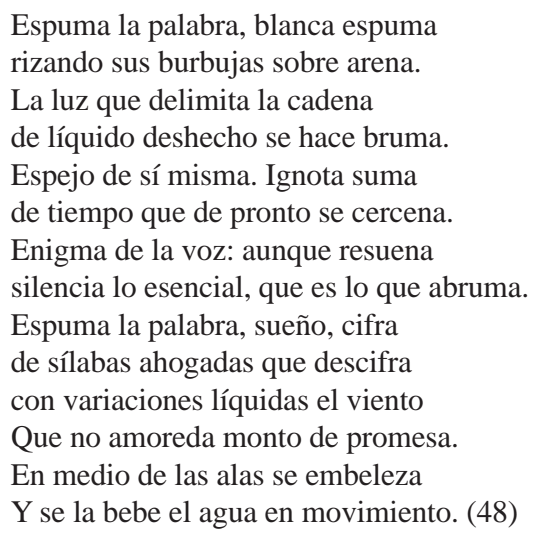

La poesía de Luna aspira a relatar el nacimiento de la palabra poética. De ahí que su primera colección describa con tanto entusiasmo esta búsqueda mitológicamente cifrada en las figuras de Orfeo y Eurídice. Orfeo se atiene a la materialidad de esa búsqueda y dictamina los parámetros de los que parte esa materialidad: el oído atento a lo que le sopla el dios y la manera en que surge sobre la página ese sonido. Sin embargo, lo que se mira se disuelve y lo que se escribe es la sombra de lo que se escucha. Hay un movimiento contradictorio de parte de quien aspira a plasmar la armonía y la precisión, pues se desencanta cuando lo dicho deviene insignificante o es menoscabado al compararse con lo escuchado. Saberlo es el conocimiento que se obtiene según esta poética de la disolución, de la evanescencia, de lo inasible, 
ya sea en la figura de Eurídice que huye y que en vano Orfeo trata de apresar, o en el reconocimiento de la erosión o el desgaste de la palabra poética.

A las palabras se las lleva el viento, tal cual a Eurídice, regresando de la muerte, la pulveriza la mirada de Orfeo. Fijar, nombrar, asir, son acciones impotentes frente al todo de los elementos. La palabra es agua que se esfuma por la acción del agua misma que la coloca en su lugar, que es el fluir. Estimo que en esto consiste la cacería inútil de Luna, y ello conlleva el reconocimiento de la distancia entre el signo oído en relación al signo escrito. El oído, o el caracol donde cae el sonido, no logra contener: "Enigma de la voz: aunque resuena/ silencia lo esencial, que es lo que abruma”, como dice el ya citado "Espuma”. Resonar es sólo sugerencia y evocación, frente a lo esencial, pero lo esencial es abismal, se halla fuera de la palabra. La palabra misma anuncia y oculta (silencia) lo que abruma. Lo dicho resulta ser entonces "sílabas ahogadas" o "líquido deshecho". "El cuello del gran cisne blanco" que interroga al hablante dariano no es más que el descubrimiento de la desestabilización de quien lo enuncia en el mexicano José Gorostiza. ${ }^{13}$

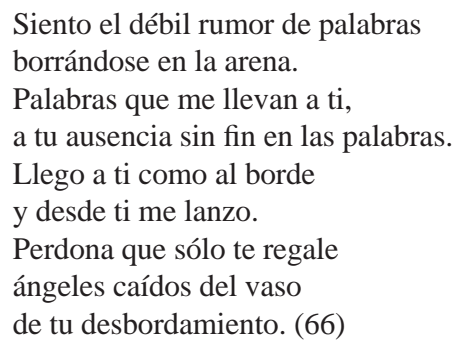

El poema es el "ángel caído” y hay una especie de disculpa por la ofrenda, el único producto posible, es decir, una resonancia "que silencia lo esencial”. De la noche (en El libro de la noche) emerge, una cierta "muerte" que lo acecha y enamora "con su ojo lánguido", fuerza que cerca también al hablante de Muerte sin fin. Eros/ ión y El libro de la noche se escriben durante el mismo período y no es raro que la metáfora de la erosión ${ }^{14}$ se reinscriba a su vez en la metáfora de la noche que es toda palabra, incluso el dónde desde el cual se dice, como advertimos en el desplazamiento sutil de la primera a la tercera persona en el siguiente fragmento. ${ }^{15}$

${ }^{13}$ Figuran como epígrafes de Eros/ión el Darío de "Yo persigo una forma” y el Gorostiza de Muerte sin fin en la cita "Mas la forma en sí misma no se cumple".

${ }^{14}$ En Selene, el libro más reciente de Luna, se dice en el poema 34: "No hay palabra que se sustraiga a la erosión que la costumbre inflige", de claro eco nietzscheano ("Sobre la verdad y la mentira en un sentido extramoral").

15 Se reiterará en el poema "Personas del verbo”, como veremos más adelante. 


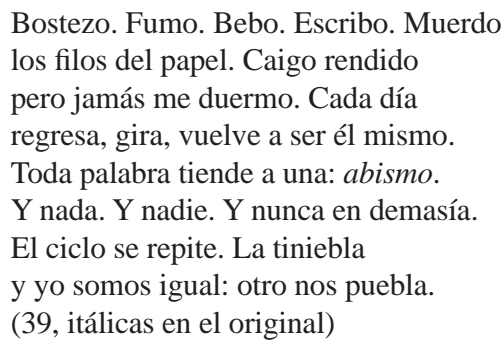

La cita de José María Lima, “se trata de tus bordes y lo que ellos albergan” reitera la busca de la forma que se inició con las alusiones a Darío y Gorostiza. El abismo es como la espuma en el agua, y se relaciona con el espejo. "Fugarse", "extraviarse" y "esquivar" son verbos presentes en esta serie y son, además, movimientos inherentes a elementos líquidos, análogos a una voz poética móvil que se la escucha pensando al hablante poético:

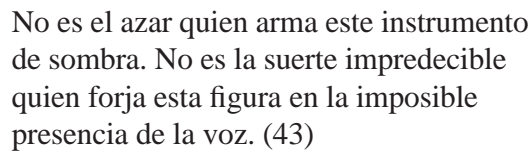

El sentido es lo que falta o lo que se oculta. La relación entre el poeta y el crítico, discutida al interior del Ión de Platón deviene en el texto de Luna una reflexión sobre el poeta como lector de sí mismo, la imposibilidad de aprehender un sentido unívoco de la palabra, la erosión misma de la metáfora en virtud del uso, y de la imposibilidad de transmitir.

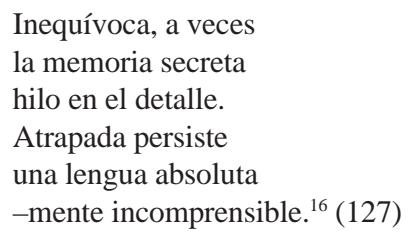

Se frotan ambas figuras (poeta y lector) en una hermenéutica que desplaza el sentido que a las palabras pueda asignarle tan sólo uno de ellos, como postulan las poéticas tradicionales. Por eso la búsqueda y el ordenamiento constante de un repertorio de objetos o palabras sobre una "mesa”, la labor nocturna que es la

\footnotetext{
${ }^{16}$ Poema final de Hilo de voz, titulado “Aún”, y con el cual termina, como una serpiente mordiéndose la cola el abecedario que es el libro, de la A a la A.
} 
escritura, el rito de la espera, los espacios cerrados donde se aloja la poesía pura de la que los textos de Luna son un excelente ejemplar constituye tan sólo un aspecto del proceso. El poeta repite la frase "sílabas de viento" y su mano escribe en la arena de forma "indecisa” y "lenta ordena" $(47,43)$. La voz es espuma, rastro, resto y tumba, abrumada de una emoción intraducible. "Isla amurallada”, dedicado a su padre, es, más que “Espuma”, el meollo de Eros/Ión:

Desde el fondo insondable que oculta densa bruma,

la voz desata al aire las sílabas de viento

y estallan en silencio cual si estallara espuma

en los gastados muros que el mar azota, lento.

Las sílabas se rompen como una débil suma

de pétalos de arena en confuso movimiento

hacia la superficie cambiante y las abruma

el ímpetu insaciable del hondo mar sediento.

En la ascensión los granos de voz dejan sonidos

de músicas antiguas y ahogadas en las ruinas

del agua. El eco nada en burbujas cristalinas

y va inundando el orbe de nombres ya perdidos.

El mar apenas roza la hermética muralla,

los granos llegan mudos y yacen en la playa. (47)

Ambos, poeta y crítico, se hallan a la caza inútil de inventar el sentido de lo dispar, el intento de los "vagos signos". ${ }^{17}$ El poeta es como Ulises, sujeto a la ordalía de nadie o de Proteo, siempre en movimiento. El poema es proteico y su hablante es Nadie, o el otro que habita en él. En "Personas del verbo", la voz poética juega con su nombre para encriptar la relación del yo con la otredad multiplicando sus posibilidades, variando, desviando, enloqueciendo la sintaxis e interrumpiendo el yo que dice "no" con la segunda persona y la antípoda de la primera, para, mediante el desvío, arribar a su nombre, Noel. A su vez tiende el puente para invocar a una tercera persona, "él”, mediada por un "tú".

Confunde la función de las palabras:

la preceptiva a veces

no es más que la manera

de describir al otro.

-No tú: él.

("Personas del verbo" 111, itálicas en el original)

\footnotetext{
${ }^{17}$ En "Ventana" (Eros/Ión) se insinúa la relación posible del poeta con el lenguaje: "El rito está dispuesto. En una hoja /en blanco se dibujan vagos signos /de los que acaso en vano se despoja /la mano, en busca de otros, fidedignos. /No hay fecha o sitio o firma. Desde el alto /de la ventana un cuerpo ensaya el salto” (29).
} 
El poeta es intérprete, lector de signos en una instancia diversa a la del crítico, pero lector al fin. Su búsqueda es reconocer la inagotabilidad del lenguaje, el hecho de la imposibilidad de dar con un sentido. Sólo hay el decir sin tocar, puro deseo,

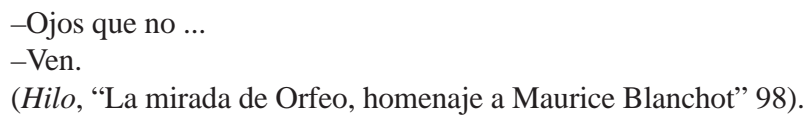

mirada órfica que nos remite al fracaso del canto para corporalizarse en Teoría del conocimiento. No se puede saber ni se puede dar con el sentido, tampoco asir. Lo que más se puede es decir con "sílabas de viento", con espuma en la boca. La poesía de Luna, deviene el proyecto de un poetizar hermético escrito de forma nítida y precisa. En Hilo de voz, tercer libro de esta colección, el mito de Ariadna, la tejedora, inicia el motivo de un hilo que paradójicamente se proyecta como voz, aunque se organiza como escritura, recorriendo las letras del abecedario. Justo antes de concluir el libro invoca al "yo" del hablante poético para decir que oscila:

$$
\begin{aligned}
& \text { ondea } \\
& \text { su tensión } \\
& \text { y vibra } \\
& \text { suave- } \\
& \text { mente } \\
& \text { justo } \\
& \text { antes } \\
& \text { de } \\
& \text { caer. (125) }
\end{aligned}
$$

La voz se suspende en el tiempo y la escritura se extiende sobre la página, como testimonio de su fugacidad. El vaivén del texto se consuma en el ir y venir por la voz y la escritura, por lo que se escucha y lo que se ve, proliferando la forma del poema breve, al borde de su inexistencia epigramática, letrista y concreta. Si, de un lado, la tradición opera como un tatuaje sobre su escritura (se trata de un libro poblado de citas), "el hilillo de voz" remite a un libro vertido a la sensualidad violenta e inestable de lo aural, y con ello el protagonismo del oído, la voz, el eco y el diálogo. Luna arriba a su "poética”: "no queda sino desearte” (113). Así emigra de la Eros/Ión del soneto, al verso libre (Poemas de la noche) y al alfabeto (Hilo de voz), casi en una trayectoria regresiva por la tradición y la palabra poética. La metáfora del hilo no conduce a la salida del laberinto, al contrario, el riesgo de perderse lo alberga al sostenerlo la palabra misma, un abismo de sentido que hace peligrar su poesía cuando se congela su metáfora. Aquí el poema no aspira a un 
decir pleno de sentido, sino que la poesía es extrañamiento de lo que nunca se ha podido decir más que aproximadamente: "No queda sino desearte".

En Selene, el libro más reciente de Luna, todo cae en su lugar. Vuelven el viento y el aire a poblar el ambiente y esta vez preside el aura de Lezama en el epígrafe "Pues el viento, el viento gracioso, se extiende como un gato para dejarse definir". Como en la música, el espacio natural de estos poemas depende del factor "viento", de la posibilidad de captar auditivamente las armonías, así como la sonoridad de los vocablos y por eso no importa decir en prosa, a borbotones e incluso ininteligiblemente, siempre y cuando se escuche o se capte la materia. El oído prefigura su centralidad:

Una secta que dedicara su esfuerzo a la estricta dilucidación platónica del caracol, ombligo del mundo, lo contemplaría acaso como portátil cielo de las ideas. Entre los sedosos pliegues retorcidos que antes cobijaran el sabroso tegumento blando de un molusco, resuena la idea, instantáneamente ahogada en el coro unísono. Cada eco refléjase en el cóncavo azogue de su contrario. Efecto de conjunto es el leve silbido de la brisa marina. (Poema 10)

Aquí la Eurídice de Teoría del conocimiento regresa en la figura de Selene/ Verónica, Eunice, y la voz poética las busca como a otras Filí-Melé, operando cual faros a lo largo del libro. Está hecha para la fuga, como las sílabas de viento, y el hablante se va abandonando a su desaparecer. ¿Qué se va y qué queda de esta fuga? ¿Qué se hunde y que se disuelve? ¿En qué trecho o en qué espacio entre el sonido y el sentido se extiende "el gato que no se deja definir”? ¿Por qué en este poemario que se fundamenta en una poética de la disolución, imitativa del movimiento de Selene, tan parecida a su huída constante, a su desvanecimiento, amenaza con ira el "abandono" a una fuerza que le es afín, como una gota imita a otra hasta agotarse? La poética de este libro consiste en trozar la palabra, desdecirse, desvanecerse. El hablante se halla sumido en la vigilia y duerme con los ojos abiertos forzando la luz de Selene en el abismo de su noche elemental. Selene se extiende para desvanecerse y su sonido protagoniza el libro: "Según la noche avanza/ se desvanecen uno/ por uno los sonidos./ Sucede poco a poco/ sin que se note apenas /la forma en que enmudecen”. La voz de Selene formula una marca sobre la piel del hablante, se le graba en la piel del texto; Selene es un tatuaje en el oído de Luna. En su caracol se desplazan sus fases y en su caja de resonancia se refleja. Otro tipo de espejo es el caracol que absorbe el sonido, como devora conjuros. La voz poética, lunática, devuelve, le devuelve, le agradece el sonido cercándola con "áureo anillo”, en el poema. Selene-serpiente lo sofoca hasta la purificación. Eunice, otra de las mujeres que aparece en el texto, es espiral, giro y danza, igual que Selene y su voz son “ondulación sinuosa”. El caracol es espiral petrificada, pero este libro es una espiral 
en continuo movimiento hacia el centro del oído donde se fugan los sonidos. ¿Qué será tatuar el rumor de Selene en la recámara del sueño? En esta alcoba recurrente visualmente en el libro, ${ }^{18}$ que es recámara del sueño y evocación visual del oído, se extiende el gato que no se deja definir. Allí escuchamos a Orfeo reclamándole a Selene/Verónica el regreso de su voz, el giro de su voz. En el oído íntimo se sigila en vigilia la noche oscura del alma, la venida bajo la forma de una fuga que resuena contra el sentido que lo torna sordo. En Selene se reitera la poética de Luna, ya sugerida en su primer libro, ahora indicada en el versículo de La Ilíada que dice: "Como en sueños ni el que persigue puede alcanzar al perseguido, ni éste huir de él”. En poesía, todas las vías están abiertas al sentido, a los sentidos. Y, en el poema, éste continúa escapando precisamente porque está constituido por signos, donde sólo presiden como emblemas comprensibles la pausa y el silencio. Lo que se invoca se disuelve, así como también se disuelven las sílabas de la invocación, todas son idas para siempre. Ello no impide que quien permanece retorne al oído, al laberinto o a los círculos concéntricos del abismo a donde todo regresa y desde donde todo viene, inagotable.

\section{ENTRE LA TRANSMigración y LA tRAdUCCión: LA POESÍA de ChLOÉ GEORAS}

De entrada, el título Rediviva: lost in trance . lations ${ }^{19}$ indica que aquí el lenguaje es cuestionado a partir de su origen y de su devenir traslaticio y traducido. Hablamos de desplazamientos, de la letra y de la errancia, cuestionándose la lengua originaria, así como la identidad del sujeto que la usa. La traducción, un concepto caro a Walter Benjamin, por lo que dice y redice del original, por lo que no se deja traducir, por lo que arroja del significado en la entrelínea, ${ }^{20}$ todos son planteamientos afines en las páginas de rediviva, publicado ya de dos formas distintas, como libro y como libro-objeto. La voz poética invita a sus lectores a leer el mismo poema en otra lengua para que apreciemos el desvío entre uno y otro texto, sin darle la posibilidad al tiempo para que haya traducción (como vislumbra Benjamin al pensar que autor y traductor son personas diferentes y que la traducción constituye, años después, prueba de su valor literario) y erigiéndose ella misma en la "traductora” de experiencias que tienen varias acepciones, sentidas de manera diferente desde una u otra lengua, español y/o inglés. Así también, la portada del libro invita al ejercicio

\footnotetext{
${ }^{18}$ El libro repasa varias fotos de una mujer en una habitación en sombras. Al respecto, véase mi ensayo de aparición próxima, "Lunático de Selene", texto de la presentación del libro, en Hotel Abismo 4 (2009) <www.hotelabismo.net>

19 Es el primer libro de la autora y cuenta con dos ediciones; en la segunda se convierte en un libro objeto.

${ }^{20}$ Véase el conocido ensayo “The Task of the Translator”.
} 
de la comparación, pues en la primera edición figura la foto de un torso femenino duplicado, en torsiones sutilmente diversas, exhortando lúdicamente a comparar a la modelo original en la foto de Brassai y la foto-autorretrato de la autora, Georas. La orientación horizontal de la foto sobre la portada permite invertir el libro y verla igual, con la diferencia de que ahora la foto que figura abajo es la ennegrecida y la de arriba la borrosa, sugiriendo en el lector la duda sobre la dupla "original-copia". El juego con la imagen prefigura la posición de la hablante poética del texto, que se desplaza a partir de las intensidades que la lengua le provoca, colocándose ella misma como su "imposible” traductora. Aquí los poemas se parecen en su traducción al español o al inglés, pero no son, no pueden ser y ninguna de las dos lenguas es privilegiada. El poemario es bilingüe en ese sentido de la imposibilidad de traducir, trilingüe acaso por lo que se dice entre líneas entre los dos idiomas.

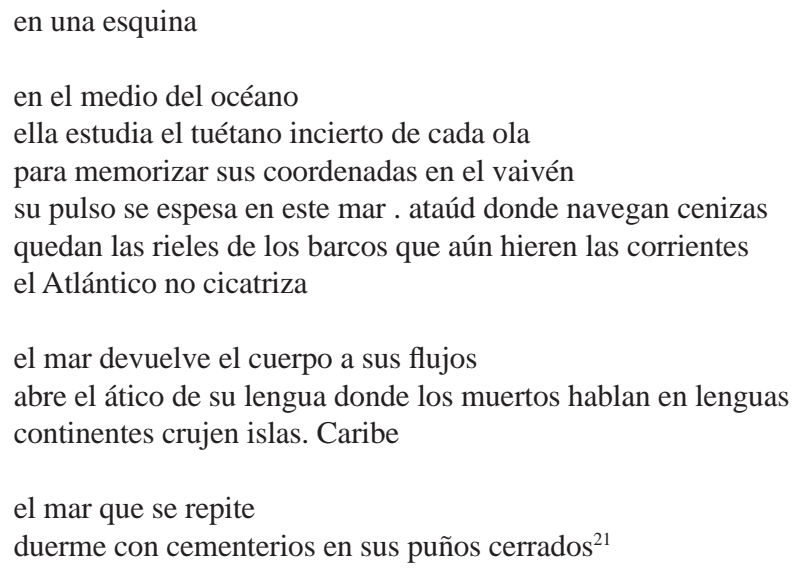

Al describir un vocablo, la autora hace de "rediviva" el estandarte del sujeto poético de su texto. El objeto encontrado de la hablante es la foto de una mujer, una modelo de Brassai que aparece en la foto Phènomene de l'extase. Hay un glosario a la entrada del texto que define a "rediviva”, y una de sus acepciones es expresión figurativa e hiperbólica de la "semejanza de una persona con otra ya muerta". Es decir, la emigrada de la muerte, la emigrante en vida, quien sufre un trance, asume la voz y relata la travesía de la mujer que se libera.

${ }^{29}$ II. At a corner/ in the middle of the desert/she unpacks/slowly removing the dusty elsewheres from her suitcase/ a sad island. Pieces of continents/ and her ocean stored away in a glove/ her skin sieves the desert into quicksand/ while from the attic at the tip of her tongue she dreams of vessels/ full of sand and skeletons/ coffins floating aimlessly over foreign seas/ships like bruises crossing the Atlantic/ she sleeps in an envelope/ with fists clenching onto exiled lifeliness. 


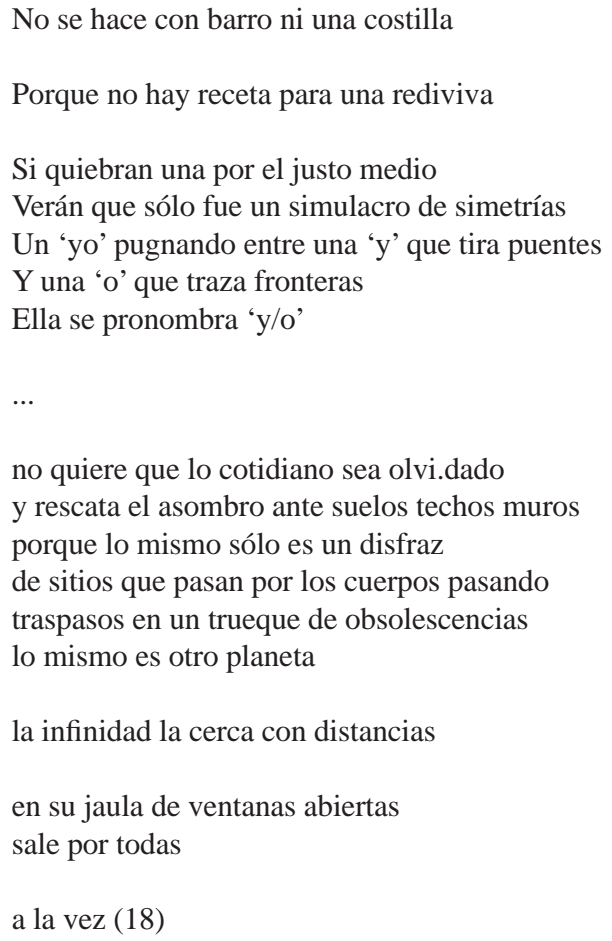

La portada también nos permite entrar en una especie de mausoleo cercado por dos columnas enormes donde parecería, por la orientación de la imagen, que yace una mujer en un sarcófago con ventana de cristal a través de la cual la vemos vestida de negro; desconocemos si ha fallecido o duerme. Ambas imágenes nos permiten percibir el vuelco que se quiere provocar en quien mira/lee: no son iguales ni la mujer ni los poemas, no es igual lo que una sola voz poética pueda hacer en inglés y en español. La conjunción/disyunción "y/o" que aparece en el poema citado es muestra del ambiguo, por ambivalente, lugar de dos en una misma zona, evocador de la foto de mujer (el cuerpo) y de la lengua (el otro cuerpo) como original y traducción, lugar de origen y lugar de deriva. "O” pero también "y”. De ahí el extravío de la traducción, de la bilocación, y no de la identidad. Por eso, en los correspondientes textos enfrentados, el desierto podría ser el océano; la lengua, un ático; el mar Caribe, el océano Atlántico, etc.

Las imágenes de disolución y evaporación cifran el cuerpo recurrente a lo largo del texto, un cuerpo femenino y un corpus lingüístico, una geografía que parecería definirse sobre los extremos de la geografía (bahías, manglares, costas, 
estuarios), flotar en la imprecisión de su contexto sobre el aire y el agua cual un mascarón de proa, un pórtico de la voz poética soñando su espacio de construcciones y deconstrucciones. La voz se plantea como una arqueóloga de sí misma buscando restos, cicatrices, tatuajes, genes que la vinculen con los semínolas, los chicanos, los emigrantes de todos los países y eras. Los unen los flujos, los pulsos y las mareas, los orificios, los lunares, las grietas y el dolor. En la diversidad ecosistémica, sin embargo, coinciden todos los humanos; en la exploración del territorio propio se descubre el territorio de todos en deriva hacia otra formación. Estos son los ejes del texto poético: primero, no hay un original; ser "bilingüe" entraña poder decir dos textos de maneras diferentes y multiplicar el espacio de lo dicho sin someterlo a la precariedad de la traducción. Traducir es trasladar, desplazarse, crear otro texto, por lo que la hablante no traduce, sino que reitera: "Cuestionamiento de la conmensurabilidad absoluta entre idiomas asumida en las convenciones de textos traducidos, tales como poner textos encarados como equivalentes”. Segundo, este drama lingüístico se enuncia en el sujeto de la transmigrante, la subjetividad nómada es también la "trance . cultural orphan" (20) que se aboca a su próxima desaparición sin pena ni lamento alguno. Como vemos, parecería que la situación espiritual es embocadura de la situación material; la transmigración del alma, figurada en el parecido físico entre la mujer en Brassai y la autora, da paso al tema que atraviesa el libro, la de la emigrante, el vaivén entre las lenguas, la posibilidad de transformación o de ser otra aún dentro de la semejanza. Pensar en el aspecto temático o semántico de esta propuesta parecería eludir el fulcro de este: el lenguaje es cifra de la diferencia en este texto que invita a una reflexión en torno a la traducción imposible, a la necesidad de decir dos veces en dos lenguas diferentes.

En una declaración de intención en su post-face (post-facio) habla Georas de la sensación que se apropia de ella cuando ve la foto de Brassai: "Yo sólo era un paradero más en la ruta imprevisible de esa palabra" (65). ("I was just another errant stop in the unpredictable route of this word”, 69). La paradoja implícita en "errant stop" coincide con un texto que evoca el mapa terráqueo (como un gran ecosistema) pero lo elude (hay más nowheres que nombres específicos de ciudades), que alude a la tierra y al mar para declararse nativa de ninguna, libre para la transformación:

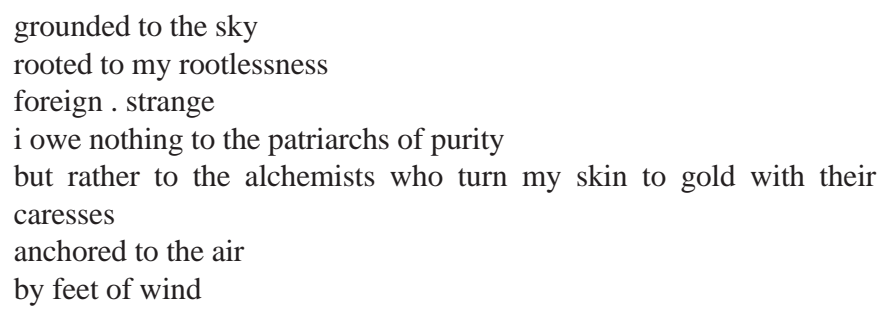


i know

there will be no turning back (30)

Al describir su libro dice Georas que explora la figura del emigrante "as living in an altered state of awareness". La hablante poética, como rediviva, como encrucijada, es esa emigrante que descubre ser el fantasma, la reminiscencia, de otra mujer. "It explores the mobile terrain of a migratory subjectivity inscribed in a body as a crossroads of historical, cultural, linguistic, emotional, and spatial flows” (69). De la misma forma, la lengua es ninguna y a su vez, dos sin posible traducción, sin posibilidad de una compatibilidad exacta, al contrario, descubriendo en su yuxtaposición la imposibilidad de traducción. ¿Qué mejor lugar para comprender la diferencia entre el inglés y el español que Puerto Rico, lugar del va y ven (vaivén) legal respecto a la oficialidad de la lengua? Más bien, a la autora le interesa el espacio entre las lenguas. Como señala, "the coming and going between languages influenced the metaphorical world created among the poems that configured a trance . lation. This book is not a bilingual edition, but rather a bilingual sedition. an uprising against the presupposition of transparency. Trance . lations are an attempt to invoke the trance of a migrant, a trader of words and spaces, in the very structure of the book" (70).

Cartografía y geografía, extranjería, extrañamiento. Pies, piel, lengua, "body on the brink unrecognizable from one mirror to another" (35), dos cuerpos, el físico y el textual se desafían. Un espacio inestable por fluido, sin fronteras pero sin tierra, aire o cielo, sin tierra: "native of nowhere", como afirma la voz poética, sobre todo, por los pies y la imagen de la deriva tan presente en el libro. Hasta la lengua es intraducible. La traducción no es tal sino traslación imposible, inconmensurable. La traducción es imposible porque no se traduce, sino que se dice de otra manera sin repetición en ninguna. En ese sentido, se trata de una lengua en tránsito y errante, una "lengua-entre" que crea un espacio lingüístico singularmente único para ambas (el libro) y manifiesta el desasosiego desde donde se dice:

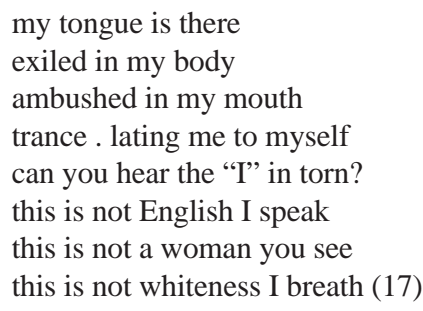


Es como si la lengua y lo que en ella se nombra se atara al cuerpo que lo enuncia de una manera singular. Pero como el cuerpo no es un yo, sino un "y/o", decir en cualquier lengua constituye una fractura que sólo tiene sentido en su propio sistema. Al menos gravita entre dos ejes, dos puntos cardinales que son importantes, por cuanto el poemario, que es una anti-cartografía, una negación del mapa, apunta hacia la fuga y el espacio abierto, a la posibilidad nueva que es cada fracaso de una traducción. Allí (there) es ningún lugar (nowhere), además de ningún cuándo, dada la ausencia de concreción que surge al fundirse lo espaciotemporal del deíctico there, que en su contexto implica nomadismo o promesa de no regresar. De otro lado, el nowhere podría ser el ahora y aquí, semejante al "y/o" o los (n)everglades del agua que se empoza: ¿never o ever?, there o where. Allí donde no se colma el hiato o la distancia entre una letra u otra es el lugar donde podría habitar efímeramente la palabra en dos idiomas de este texto-cuerpo fantasmal: "body on the brink/unrecognizable from one mirror to another". (35) La diferencia semántica entre extraña (strange) y extranjera (foreign) es su afirmación y el lugar de su lengua ("my tongue is there/ exiled in my body") requiere la imprecisión del deíctico para tornarlo aún más distante e incierto. Se trata de coordenadas que se nombran, pero cuyo mapa no carga con su orientación en el texto:

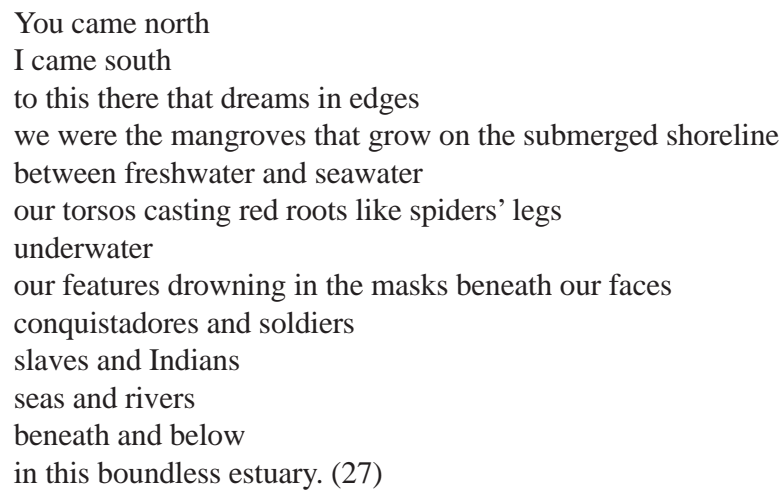

Este cuerpo ¿es silencio, ausencia, límite o fuga? "En cuerpo de mujer” lo define: es una suma de silencio y oquedad, una diáspora de sí misma, "un litoral delicuescente", pero no es liso, ningún cuerpo lo es, como tampoco lo son los panales, las telarañas, los corales ni los fósiles a lo largo del texto. La "traducción", la locura, el traslatido o traducción de "en cuerpo de mujer" es "darkness" (36-7) abismal. El dolor es inconmensurable, y la voz poética no hace más que excavar el fósil de su cuerpo. Exploración. Investigación. Implosión. Exposición. Hay cosas que se dicen en inglés, pero no en español, y viceversa. La lectura simultánea de 
los dos textos produce relaciones poéticas inusuales: una embarcación podría ser un ataúd o el océano puede ser el desierto, y “a sad island” es imposible descifrarla en medio del desierto que es el Atlántico..$^{22}$ Aquí el yo se deshace de su cuerpo para mirarse desde fuera, pese al dolor. El dolor como una mirada, como el escalpelo de la mirada, recorre el cuerpo para subrayar sus pies, su lengua, su piel, es decir, el espacio de su muerte y de su propio comienzo, el límite mismo, la frontera donde se tramita o se traslada el paso entre lo vivo y lo muerto. Rediviva es la promesa de la voz poética: “y/o”, no yo, la fuga por todos los resquicios.

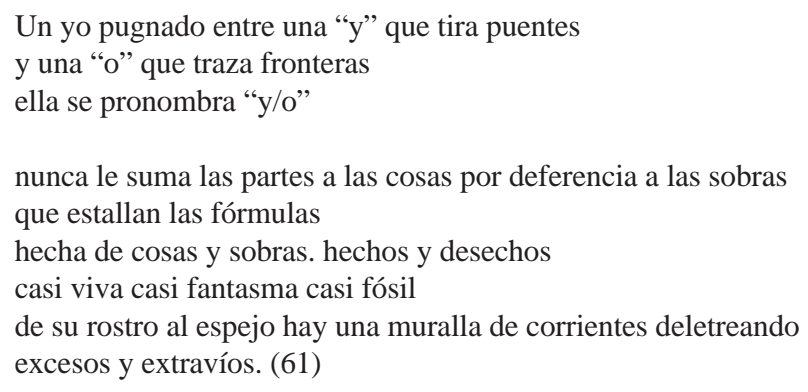

La portada semeja una entrada al mundo de la rediviva, a un mausoleo donde se recogen poemas-epitafios. El aire fúnebre del texto ronda lo fantasmal, mas la imagen de la rediviva, de un alguien que regresa de la muerte, multiplica sus posibilidades en el "y/o", en lugar del yo. No hay certezas ontológicas, sino marcas relativas a los titubeos o las elecciones que dirigen una vida. Este tema se recalca en la segunda edición del texto como libro de arte donde se hace visible la coexistencia de dos textos simultáneos a través de una transparencia opaca, como la del papel. El libro de arte incluye materiales emblemáticos tales como curitas, esparadrapos, gasas, espejos, para reinstalarse en el tema del dolor. Pero visualmente las transparencias facilitan ver algo más allá de la página, la próxima página que aparece opacada u opalescente, el profuso palimpsesto que nos permite leer pain y dolor simultáneamente pero sin pena, como una necesidad de rastrearse objetivamente, arqueológicamente, hasta culminar con la promesa última: estallar es salir develando el espacio en blanco que se halla en la cajita del sarcófago. Diversa en énfasis a la lectura del texto realizada por Dorian Lugo Beltrán, curador del libro-objeto, relativa a los huecos, las heridas, las ausencias que carga todo cuerpo, me interesa el dolor que faculta, el dolor que tramita, el dolor que edifica. Más que la carencia, el poema final sugiere la promesa. No hay nada más fructífero que "perderse" entre dos sistemas de signos (el español frente al inglés y el signo lingüístico frente al signo visual),

${ }^{22}$ Me remito a los poemas "En una esquina”/ "at a corner”. 
la fenecida frente a la traducida, el original frente a su derivado, la edición frente a la sedición. La foto Phenomène de l'extase, portrait de femme, alrededor de la cual gira la imaginería de la hablante poética en trance de inventarse y traducirse en otro medio y en otro idioma, reposa al final del libro fuera del túmulo o sarcófago, en una sobre-exposición de los entornos. Allí se describe:

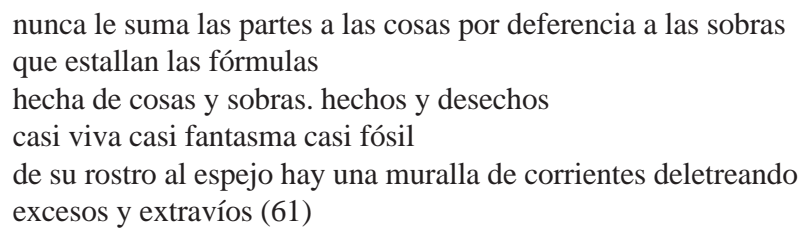

Y la definición:

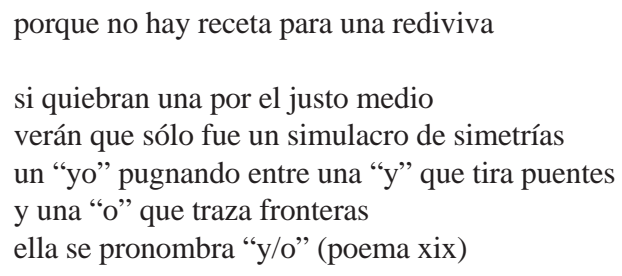

Se torna imposible calcular qué es un "y/o" frente a un yo o traducir qué significa un esparadrapo envuelto en una bolsita de celofán que dice: "Active ingredients: forced silences, pulses and corridors", o el espejo colocado frente al poema "xiii, me desnudo" o los esquineros en donde se adhiere el vacío de una foto o una foto ausente o invisible. No hay nada como lo real, nos dice el libro-objeto. Si se comienza con una puerta-espejo por donde se mira un cadáver y luego la puerta aparece en negativo, algo dice la foto cuando emerge liberada de su encierro. El diálogo entre la imagen y las palabras que la acotan es crucial:

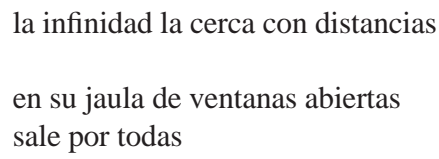

La de Georas es una poética a velar por la promesa que anuncia desde los dos espacios del nowhere, buscando el afuera de la semejanza y cuestionando la 
dicotomía de lo original y la traducción. La sugerencia es multiplicar las lenguas del decir, cultivar el intervalo entre el origen y su otro origen, más bien desde un lugar entre fantasmal y potencial que le entrega al lector -cualquiera- para que lo construya.

\section{Rebollo Gil: poÉtica PARA El CONSUMO y GENEALOGÍA}

Las respectivas poéticas de un grupo de poetas también contemporáneos denotan que se perciben a sí mismos como lectores en voz alta o "performers", intentando leer ante un público simpático que no lo comprende (José Raúl González, alias Gallego) o ante una audiencia de quien se mofa y rechaza secretamente (Urayoán Noel) o de una que retrata y convierte en su interlocutora en una íntima complicidad (Rebollo). Esa visión de la audiencia, valorada de forma diferente, distingue entre sí a estos tres poetas-performers. ${ }^{23}$ Su exploración de los espacios públicos para representar allí su poesía resulta interesante dadas las inquietudes que pueda suscitar respecto al concepto de "literatura" sobre el que reflexionó el maestro Ángel Rama en La ciudad letrada, a saber, la relación entre la literatura y el poder. A efectos de mejor describir esta poesía es urgente incorporar el concepto de sociedad del espectáculo, tan bien descrita por Guy Débord, y uno de cuyos puntales es la afirmación de lo social como apariencia. Ese es el propósito principal de esta sección. De la universidad o sus espacios, los poetas se trasladan a leer en el café, la barra o la librería. El espacio tradicionalmente ligado al saber se sustituye por el del ocio, el entretenimiento y el consumo. Pero, además, en esa tarima improvisada que coloca un podio al revés o se arriesga a competir con un público a veces ausente para captar su atención, el yo tiene que enarbolarse con toda su fuerza. Hay un rigor en dichas presentaciones, que consiste en mantener al público entretenido. La doble exploración del libro y la tarima por parte de este sector de la promoción concentrada en Rebollo, Noel y Gallego genera estallidos imprecisos con visos políticos que hallan sus antecedentes en la poesía nuyorican de Pietri, Laviera y Algarín.

De Guillermo Rebollo-Gil, el poeta más interesante de los tres, quiero discutir su poética, centrada en lo que considero su mejor libro, Teoría de conspiración. Este sostiene un espejo para que el lector de esa sociedad de consumo se contemple y se ría (de sí). Dicha poética se anuncia desde el 2000 en Veinte, su primer libro, donde en el poema inicial se insiste en una "voz poética generacional" que transita

\footnotetext{
${ }^{23}$ Sobre la poesía puertorriqueña y el performance me remito a mis "Cuerpo Caribe: entre el performance, la poesía (y el tono... su esplendor)” y "El cuerpo, ese tropo: algunas escrituras contemporáneas” ambos en Femina.
} 
desde un yo a un nosotros sumido en su propia clase. El "blanquito"24 de Caparra, máscara asumida por la voz poética, dice en el poema "prólogo”:

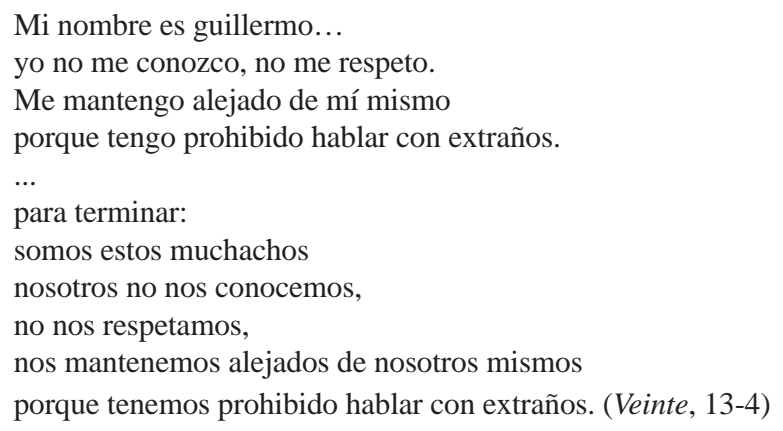

Esta voz poética tiene conciencia del lugar que ocupa socialmente, del lugar que crea generacionalmente y del ciclo completo de la producción y consumo del texto. Acaso no haya un poeta que desconstruya con mayor rigor que Rebollo el lugar del libro y del espectador-lector en la "sociedad del espectáculo", en la que Puerto Rico desempeña un lugar destacado. El poema “proclamación de una dependencia dependiente” expresa:

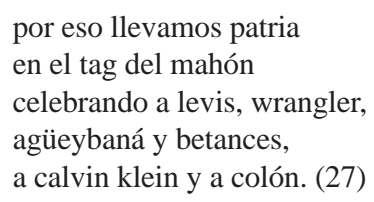

La marca de un nacionalismo-espectáculo, muy distante del nacionalismo albizuísta, ${ }^{25}$ se ostenta en la alusión a la creación de un solo cuerpo-bricolage en el que se yuxtapone tag con patria y coexisten armoniosamente Agüeybaná, Betances, Cristóbal Colón y Calvin Klein, todo bajo la premisa de que se trata de una sola patria. Tampoco falta el comentario referente al puertorriqueño como ciudadano de segunda clase de los Estados Unidos, explorando los visos de similaridad inherentes a las palabras alienígena y extranjero en el contexto de la ley de inmigración norteamericana. En "Puerto Rican as in alien. as in citizen” (Veinte, 43) o en el brillante "talibán borikua” se destaca la mirada imperial que iguala todas las diferencias bajo el clima paranoico del terror:

${ }^{24}$ El vocablo puertorriqueño constituye una alusión irónica a la clase alta, mayoritariamente blanca. Caparra es una zona afluente de la ciudad capital.

${ }^{25}$ Distíngase en "La imaginería nacionalista: de la historia al relato" en mi Hilo de Aracne. 


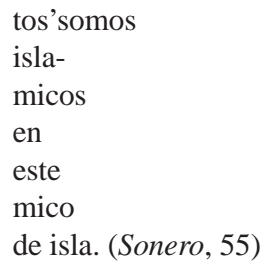

Aesta compleja sociedad puertorriqueña le presenta su máscara de "blanquito"; a su propia generación y clase le dedica su producción, cuestiona sus políticas correctas, no sin antes imprecar la figura del padre, herida recurrente en cada una de sus entregas poéticas. Es ésta una voz poética que insiste en retratar al poeta "adolescente" del suburbio acomodado como protagonista y, a su vez, público de estos poemas. El poema "mi ex se fue o pequeña diatriba racista contra el racismo o de cómo los blancos se tumban todo lo negro por fashion y le quitan el significado" es un excelente ejemplo donde el escenario es el conflicto racial, el colegio, los amigos y la urbanización de clase alta, Montehiedra:

mi ex se fue con un blanquito cool

con un wanabi gringo bongosero rasta

con dradlocks tipo bob

pero rubio

que le mandaba señales de humo

a mi ex en la escuela.

y continúa:

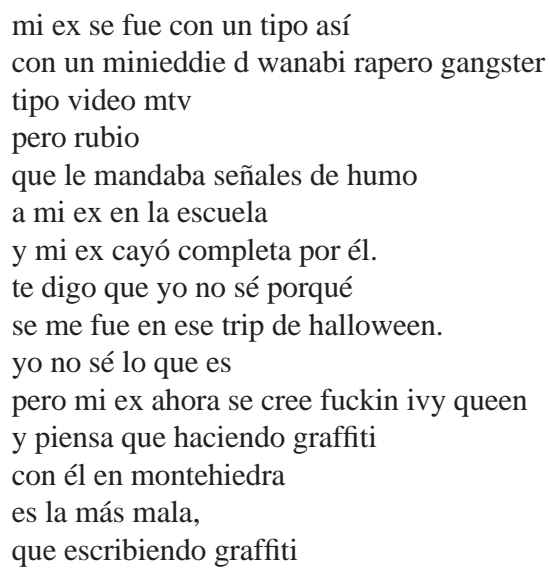


en montehiedra se pone prieta, que el graffiti en montehiedra

la ve y le dice “oye negra”. (Teoría de conspiración, 37-8)

$\mathrm{Al}$ invocarlo directamente, Rebollo hace añicos el feeling de la simulación, el populismo de las clases altas, el síndrome Guaynabo City, los referentes culturales diversos, y asume para sí la "tiraera" o el ataque personal al uso entre los reguetoneros, transportándolo a la poesía cuando toma como blanco a dos poetas de la promoción de los setenta, José Luis Vega y Hjalmar Flax. En "tiraera” (2) define a su público-comprador, dependiente principalmente de la oposición entre sus respectivas capacidades adquisitivas delimitadas por el área urbana que ocupan: Garden Hills, Caparra y Guaynabo vs. Carolina.

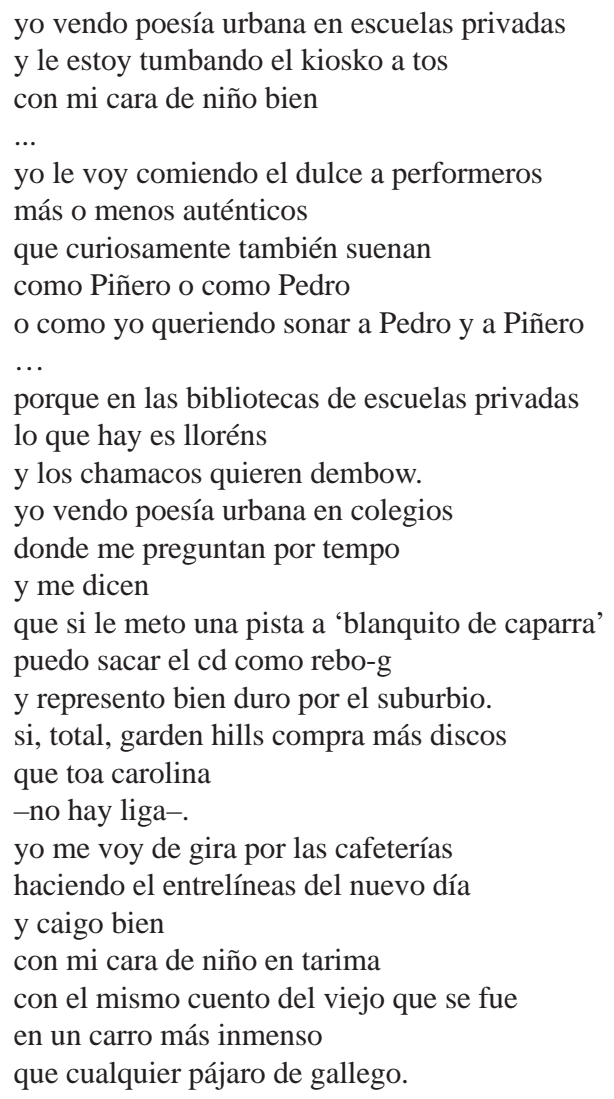




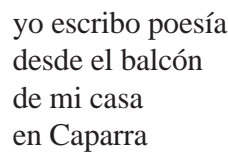

y la vendo. (Teoría de conspiración, 39-40)

Uno de los elementos más interesantes de un poema cómo este es la desmitificación del lector, convertido en público, desplazado de los centros culturales tradicionales, ubicado en una transicional fase de crecimiento y quien sociológicamente ha adoptado como suya la cultura popular. La música es un indicio de ello, se trata de poemas para ser cantados o bailados a unos ritmos particulares. Si nos atenemos a la sociedad del espectáculo, la cual se centra en lo visible como índice de realidad, ésta ha hecho de la juventud, de la cultura visual y musical, uno de sus estandartes, con el propósito de venderla. Su fin es el consumo, como se destaca en este poema. Se trata de "imágenes-objeto" que incluyen a la voz poética misma dispuesta a una gama infinita de transformaciones:

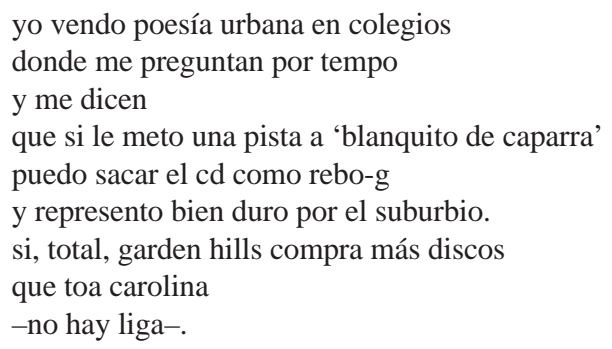

Con la metáfora de la "competencia” llega al punto de compararse con otro poeta de su misma generación, José Raúl González (Gallego), cuya voz poética evoca otros espacios y experiencias. La voz poética de González es la de un narrador de historias que identifica y descubre escenarios típicos, pero no turísticamente mostrables de una ciudad-Santurce-como sitio de muchos eventos. ${ }^{26}$ Su apoyatura

\footnotetext{
${ }^{26}$ El poeta Federico Irizarry Natal ha descrito en González la diferencia entre "la reterritorialización de los espacios perdidos” y su forma de resistirlos como parte del “oficio poético desde la misma tarima urbana" vs. el "imponente brillo del open mic, [que] pulula todo tipo de gangarilla dispuesta a hacer de la poesía y de la gestión performática un vodevil efímero y cínicamente cool”. Concluye que Residente del lupus "se nos presenta como un libro que apuesta abiertamente por la autenticidad". "Invitación a Residente del Lupus” que figura como prólogo en dicha edición (8). Véanse además los comentarios de la poeta Irizelma Robles en la contraportada de la edición, refiriéndose al libro como "exequia fúnebre de un amor desencontrado, de una casa deshabitada, de un cuerpo mutilado por el hastío y el dolor".
} 
básica es una voz sumida entre el desconsuelo y la crítica social. Evoquemos, a título de ejemplo, un poema de Gallego y veremos inmediatamente las diferencias:

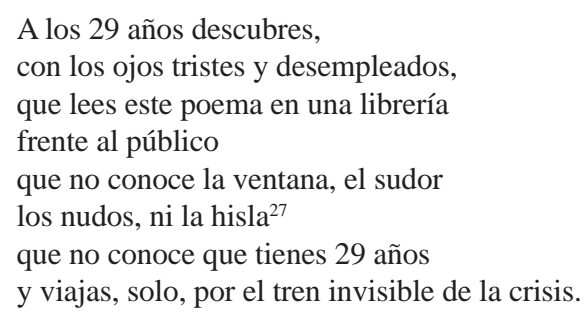

(Residente del lupus, 57)

El poema "Fake it til you make it" es una síntesis de la imitación, el cine, el televisor, la subcultura como moda, la pobreza convertida en mercancía, la simulación de la pobreza. El hablante poético recalca el rostro que ha asumido, explota irónicamente su máscara, conoce el potencial de su mercancía, de su clientela y de sus preferencias. Ha convertido su texto en un espejo para que se miren y ahí radica el estremecimiento. La paradoja es que puede tenerse noción del espectáculo, pero no salir de él. No hay un espacio privilegiado desde donde mirar y la voz poética se abisma en él con las armas que tradicionalmente son las suyas, la ironía. Desde las contradicciones ínsitas a esa misma sociedad-espectáculo, la voz poética habla, no sin antes reconocer que circula perpetuamente en un cauce del que no puede sustraerse, por la fuerza de su arrastre. Como señala Débord:

El espectáculo es el momento en que la mercancía ha logrado la colonización total de la vida social. La relación con la mercancía no es sólo visible, sino que es lo único visible: el mundo que se ve es su mundo. La producción económica moderna extiende su dictadura de modo extensivo e intensivo. En los lugares menos industrializados, su reinado ya está presente a través de algunas mercancías-vedettes y, en tanto dominación imperialista, por las zonas que encabezan el desarrollo de la productividad. (Segmento \#42)

¿Quién dice que los productos culturales, inclusive la poesía, no se han convertido en mercancías-vedettes? Nada escapa al universo de la toda-mercancía. En este libro subyacen referencias a una cultura del espectáculo con instancias subversivas que la pueblan subrepticiamente; de otra forma no habría un lector que ríe, piensa o lee y el poema no tendría oportunidad de ser comprendido. Ya la voz poética define el fenómeno en "pop poetry”: "lo insólito siempre está a punto/

\footnotetext{
${ }^{27}$ Recurso ortográfico para aludir a Puerto Rico a lo largo de todo el libro.
} 
de suceder a tus espaldas” y consiste en volverse comercial, y acota la voz poética "sigues así sin tocar fondo" (17). No hay progreso posible aquí, nos hallamos en el mismo día (“el tiempo irreversible de la producción”, Segmento \#146), en la misma aldea global, en el mismo sujeto: la voz poética mirándose en su público y viceversa. Se trata de un tiempo abstracto dominado por la ilusión, donde todo se convierte en mercancía. Esto torna aún más interesante Teoría de conspiración porque nos permite pensar cómo el poema hace posible, por las rupturas que entraña -metafóricas, sintácticas-, la "salida” ambigua hacia otro lugar, la crítica inherente a todo arte, subrepticia y sediciosa.

La conspiración, vocablo proveniente del derecho penal, coloca en la mira a la sociedad puertorriqueña-global que se contempla aquí. Un análisis semántico de gran parte de las metáforas recurrentes en el libro yuxtapone la zona de la genealogía familiar con el crimen de cuello blanco, modificando ahora la lectura que podamos hacer de este texto en el registro del delito que permanece impune. La metáfora de la enfermedad (el lupus) en el poeta Gallego halla correspondencia en la metáfora de la genealogía en Rebollo Gil. Este es el pie no forzado de una poética que parte de una desconstrucción de la familia. Proveniente de una clase acomodada, en tono confesional, el hablante comienza imprecando al padre, fantasma que atraviesa toda su obra, y se burla sarcásticamente de la ventaja de vivir en Caparra, tener un público más afluyente que el de Gallego, describir pormenorizadamente la simulación que hace un sector de la clase pudiente de lo que está in o fashion y utilizar un lenguaje ambidextro (irónico, lírico, resentido en inglés y español, tradicional y posmoderno) para desarticular el lugar del lector. Reminiscente del lugar crítico de la referencia narrativa de Rosario Ferré a su propia clase, Rebollo se burla de la crítica a la crítica que él mismo inventa o simula o principalmente explota para escribir y, sobre todo, "vender" poesía. Se trata de una poiesis singular. La guerra en Irak o la presencia de la marina en Vieques son lugares políticos reales, transformados en espectaculares por la sociedad del espectáculo, prestándose a ser explotados de diversas formas por ideologías maquiavélicamente diferentes. El planteamiento a medias escondido de una conspiración, una ocultación sotto voce de los delitos de cuello blanco, la urbanización cerrada donde todos se codean con todos, la estirpe echada a perder por contraer matrimonio con su propia progenie, hasta la protesta misma, reciben el impacto súbito de la crueldad:

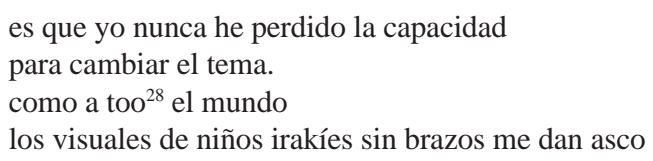

\footnotetext{
${ }^{28}$ Obsérvese el lugar en que el poeta opta por utilizar el apócope de “todos”.
} 


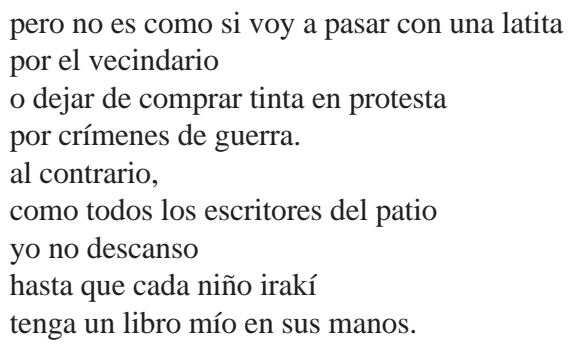

(“otro poema comercial de protesta”, 28)

Por otro lado, el vocabulario heredado de la criminología y la sociología, disciplinas que conoce en profundidad el autor, permite leer Teoría de conspiración de forma plurivalente. El hablante comienza por desconstruirse a sí mismo y pone en vilo a toda una progenie tendida sobre la corrupción (el padre o algunos familiares), el vecindario (pudiente) y su propia generación (la simulación). El crimen de cuello blanco ronda estas páginas, así como la emigración de una clase profesional a los Estados Unidos. Nada escapa, ni siquiera él mismo, al escarnio. En esto se distingue de José Raúl González (Gallego), cuyo hablante se "salva" de la autocrítica al ubicarse entre aquéllos surgidos de la desigualdad. Y difiere de Urayoán Noel, que se distancia del panorama o del escenario por la impronta tan vigorosa de su afirmación como performer. Rebollo, sin embargo, se las juega frías, colocándose en el medio, pero con sonrisa. Estimo que es el proyecto poético más complejo de todos. Su posición como performer es una máscara más, asumida como parte de una estrategia de venta donde la simulación es parte del paquete. Poesía que salta como en un libro infantil (pop ups), "tira'era" entre poetas imitando el estilo reguetonero (y escogiendo como blanco la "persona” de Hjalmar Flax, el poeta irónico de la generación del setenta), poéticas dentro de poéticas fingidas. La puesta en abismo de su propia poesía y de su propia persona le permite hacer mejor poesía, la autorreferencialidad se auto-desconstruye.

Al finalizar el libro, el lector desconoce si habla en serio o lo simula, al defender la espontaneidad de la poesía y a un juez que emite su veredicto respecto a su eficacia: "O las coges en el acto/ o las palabras/se hacen pasar/ por jueces/en la página/y se inhiben” (57). Esta poética presuntamente espontánea es una ilusión más para insistir en la temática más política de todas, con una addenda poética que linda con lo estético en el homenaje al poeta nuyorican Pedro Pietri. La estructura del poema remite a un hear-say que atraviesa el texto, consistente en el rumor de que Pietri ha muerto, lo que da pie a que la voz poética lo convierta en una especie de mito que manipulan todos y trate de distinguir entre escucharlo y leerlo, pegando paradójicamente "la oreja a la página”, contextualizando sus referencias y asimilándolas a las suyas, pese a reconocer su dificultad. En otras palabras, el 
poeta, puesto en el espacio del lector de Pedro, reconoce la imposibilidad de esa lectura. Mucho podría significar esto cuando insistimos en que Rebollo descompone, por así decirlo, la "autenticidad" de lo que algunos han llamado poesía-calle. La poesía de Pietri, probablemente el primer poeta-performer nuriqueño, rebasa el libro cuando de leer se trata. Cuando Rebollo lo imagina leyendo en voz alta se ubica dentro del "tiempo irreversible de la producción de mercancía" y sucumbe a ese juego sabiéndolo. Pero al invocarlo, a Pietri y a su tradición, asistimos a un fenómeno interesante: el poeta puertorriqueño, nacido y criado en Puerto Rico se desea colocado de lleno en el mainstream de la misma sociedad de consumo, anclada territorialmente en otras estrategias de venta. ¿Significa algo nuevo este fenómeno? Su incorporación del inglés en los textos, por ejemplo, conlleva una marca de clase, pues no es el inglés del barrio, sino el inglés que hablan otras clases. Así también los referentes a los Estados Unidos, realizados desde contextos puertorriqueños, provienen de otro lar. Algo querrá decir este reconocimiento temprano del joven poeta que hace estudios de bachillerato en los Estados Unidos y allí permanece. El que en el prólogo a Veinte ya Efraín Barradas lo ubicara en otro lugar, junto a otra tradición de la poesía puertorriqueña, tiene mucho que decir.

Rebollo es el poeta cool de su generación. Se trata de una figura intermedia que hace equilibrio entre la lectura de poesía y el texto, aunque parece haber hallado su espacio más en la página que en el espacio público. Ello coincide con textos autorreferenciales donde se representa y caricaturiza a la clase social alta, a la cual contempla y ante la cual desea establecer distancia. Comparte Rebollo con la conocida escritora Rosario Ferré una misma pasión por escudriñar la clase social de la cual proviene, convirtiéndola en uno de los puntales temáticos de su proyecto escriturístico. Absolutamente irónico hasta consigo mismo, consciente del teatro que es la escritura, no quiere desempeñar el papel de performer tan rígidamente como lo asumen otros. Esa desubicación y esa ambigüedad, ese trabajo con la ironía posmoderna, lo coloca en un lugar otro, repleto de posibilidades.

\section{RECAPITULACIÓN}

Tour de force le llamo a esta selección, forzada por el imperativo de la brevedad, aunque orientada por un deseo honesto de leer a estos cuatro poetas de los noventa, interesantes por haber construido libros precisos y hermosos, donde el hablante poético estipula, por así decirlo, su poética. Pese a la diferencia entre las voces, el proyecto estético es evidente. Ya sea mediante el poema en prosa, el soneto, el poema breve, el poema libre, los temas recurren: el poema filosófico, la travesía existencial, la muerte, el amor, la crítica social, la comunicación, la escritura. Son poéticas donde la exterioridad es indecible, por más realistas, geométricas, puras 
o confesionales que parezcan algunas de las propuestas irónicas, intraducibles, inefables, subjetivas; también imposibles de comprender a menos que recurramos a la perenne necesidad de la voz poética de leer al otro dentro de sí mismo.

Podría ir armándose el mapa de la poesía puertorriqueña de los últimos cincuenta años a partir de una opción de lenguaje. En este sentido, es determinante por crucial la poesía de los setenta, década en que la poesía puertorriqueña se libera de los temas consabidos para insistir en la escritura. Agotado el recurso de la representación, de la ideología, del salvacionismo político, dichas voces optan por explorar todo lo que ofrezca el lenguaje. El hablante irónico de un Nicanor Parra, la poesía en prosa de Vallejo, la cotidianidad de Ernesto Cardenal, la reflexión sobre la forma de un Gorostiza y otros poetas latinoamericanos figuran como fuerzas emancipadoras, junto con la lectura insistente de la poesía europea y la literatura oriental, incorporada a través de Octavio Paz y Tablada. Son los poetas de los setenta los que recogen la tradición de recitar ya no en parnasos o ateneos sino en cafés y bares, insistiendo en el poema más que en el tema y son éstos los que más vigorosamente reconocen la necesidad de escribir su crítica. Proliferan las revistas: Penélope y el otro mundo, Zona de carga y descarga, Ventana, Reintegro, las cuales darán paso posteriormente a Filo de juego, Piso 13, El sótano 00931, y otras, tales como Postdata, Nómada y Hotel Abismo. Tampoco puede pasar inadvertido el papel desempeñado en una época (durante dos décadas) por la sección “En rojo” del periódico Claridad y las antologías que con mayor o menor honestidad intelectual se van publicando a lo largo de los años.

Cuando leemos textos de Rafael Acevedo, Guillermo Rebollo Gil, Irizelma Robles, José Raúl González, Javier Ávila, Néstor Rodríguez, Federico Irizarry Natal, Kattia Chico, Juan Carlos Rodríguez o los poemas inéditos de Yara Liceaga, por sólo mencionar a algunos de los más destacados, no podemos dejar de pensar en la importante promoción de los setenta, que continúa en plena producción: Vanessa Droz Martínez, Luz Ivonne Ochart, Lilliana Ramos Collado, Rosario Ferré, Joserramón Meléndez, Néstor Barreto, Olga Nolla, Hjalmar Flax y José Luis Vega. Podríamos trazar un intenso diálogo entre generaciones, la del setenta y la del noventa, de la cual Luna, Georas, Figueroa y Rebollo son excelentes exponentes. Afortunadamente, para la crítica, mucho queda por decir. Lamentablemente, sobre la poesía puertorriqueña, mucho se ha dejado de decir. 


\section{BiBLIOGRAFÍA}

Benjamin, Walter. “The Task of the Translator”. Selected Writings. Marcus Bullock y Michael W. Jennings, eds. Cambridge: Harvard UP, 2004. I: 253-63.

Débord, Guy. La sociedad del espectáculo [1967]. Edición, crítica y prólogo de Christian Ferrer. Buenos Aires: La Marca, 1995.

Deleuze, Gilles. Seminario sobre Leibniz. Ernesto Hernández B., trad. <http://www. webdeleuze.com/php/texte.php?cle=133\&groupe=Leibniz\&langue=3>

Figueroa, Sylvia. (pAra mirar de cErca). San Juan: Fragmento/Imán, 2007.

Georas, Chloé. Rediviva. Lost in trance. lation. San Juan: Libros Nómadas, 2001.

Rediviva. Lost in trance. lation. San Juan: Isla Negra, 2004.

González, José Raúl. Residente del lupus. San Juan: Isla Negra, 2006.

Luna, Noel. Teoría del conocimiento. San Juan: Editorial de la Universidad de Puerto Rico, 2001.

Hilo de voz. San Juan: Terranova, 2005.

Selene. San Juan: Fragmento/Imán, 2008.

Fiel fugada. Antología poética de Luis Palés Matos. Edición de Noel Luna. San Juan: Editorial de la Universidad de Puerto Rico, 2008.

Man, Paul de. Visióny ceguera: ensayos sobre la retórica de la crítica contemporánea. Traducción y edición de Hugo Rodríguez Vechini y Jacques Lezra. San Juan: Editorial de la Universidad de Puerto Rico, 1991.

Rebollo Gil, Guillermo. Veinte. San Juan: Isla Negra, 2000. Sonero. San Juan: Isla Negra, 2003.

Teoría de conspiración. San Juan: Isla Negra, 2005. La carencia. San Juan: Terranova, 2008.

Sotomayor, Áurea María. Hilo de Aracne. Literatura puertorriqueña hoy. San Juan: Editorial de la Universidad de Puerto Rico, 1995.

Femina faber, letras, música, ley. San Juan: Callejón, 2004.

De lengua, razón y cuerpo. (Ensayo introductorio y antología sobre varias poetas puertorriqueñas contemporáneas). San Juan: Instituto de Cultura Puertorriqueña, 1987.

Valéry, Paul. "Poésie et pensée abstraite”. Oeuvres. París: Gallimard, 1968. I: 1314-39. 